\title{
Competitiveness and Profitability of Intercropping Sunflower with Peanut under Different Irrigation Water Levels and Potassium Fertilizer Rates
}

\author{
Samiha A. Ouda ${ }^{*}$, Yaser A. A. Hefny'2, Tamer I. Abdel-Wahab ${ }^{2}$, Sherif I. Abdel-Wahab ${ }^{2}$ \\ ${ }^{1}$ Water Requirements and Field Irrigation Research Department, Soils, Water and Environment Research Institute, Agricultural \\ Research Center, Giza, Egypt \\ ${ }^{2}$ Crop Intensification Research Department, Field Crops Research Institute, Agricultural Research Center, Giza, Egypt \\ Email: *samihaouda@yahoo.com
}

How to cite this paper: Ouda, S.A., Hefny, Y.A.A., Abdel-Wahab, T.I. and Abdel-Wahab, S.I. (2018) Competitiveness and Profitability of Intercropping Sunflower with Peanut under Different Irrigation Water Levels and Potassium Fertilizer Rates. Agricultural Sciences, 9, 1007-1031.

https://doi.org/10.4236/as.2018.98070

Received: July 9, 2018

Accepted: August 24, 2018

Published: August 27, 2018

Copyright (c) 2018 by authors and Scientific Research Publishing Inc. This work is licensed under the Creative Commons Attribution International License (CC BY 4.0).

http://creativecommons.org/licenses/by/4.0/

\begin{abstract}
A two-year study was carried out at Ismailia Agricultural Research Station, Egypt during 2016 and 2017 summer seasons to evaluate competitive effects of intercropping sunflower and peanut under different drip irrigation water amounts and $\mathrm{K}$ fertilizer rates for increasing farmer profitability. Three irrigation amounts (70\%, 100\% and 120\% ETo), three K fertilizer levels (57, 86 and $114 \mathrm{~K}_{2} \mathrm{O} \mathrm{kg} / \mathrm{ha}$ ) and four intercropping patterns of sunflower and peanut (different spatial arrangements) were implemented. The experimental design was strip split plot with three replications. The results showed that there were no significant differences between $100 \%$ and $120 \%$ ETo on most of yield traits of the intercrops. The highest $\mathrm{K}$ fertilizer level had the highest values of most yield traits of the intercrops. The highest values of peanut and sunflower traits were obtained from intercropping sunflower with peanut, where peanut seeds were sown on both sides of all the raised beds, sunflower seeds were sown on one row above the raised beds and the following bed was left without intercropping (P1). Thus, to attain the highest yield of intercrops and water equivalent ratio (WER), the lowest competitive pressure and the highest farmer profitability, $120 \% \mathrm{ETo}, 114 \mathrm{~K}_{2} \mathrm{O} \mathrm{kg} / \mathrm{ha}$ and $\mathrm{P} 1$ intercropping pattern should be implemented. This research found that the result of competitiveness was consistent with the result of profitability.
\end{abstract}

\section{Keywords}

Drip Irrigation, K Fertilizer, Intercropping Sunflower with Peanut, WER, Competitive Relationships, Profitability 


\section{Introduction}

In general, nutrients, water and light are the three main classes of resources that limit plant growth and are considered to be resources for which individual plants compete. The effects of competition are widespread and easily observed in different intercropping patterns. The complexity of resource competition is derived not only from the variability of resource limitation in space and time and among species, but also from the complexity of the resources themselves. Nutrients, water and light each differ in their properties, which generates unique ways that plants compete for these resources [1].

In Egypt, drip irrigation management could be an important factor to minimize the inter-specific competition between oil crops for basic growth resources under sandy soil conditions. Drip irrigation markedly increased yield and shortened the growing season over sprinkler or furrow irrigation and offered the best method of supplying uniform soil moisture in the root zone throughout the growing season [2]. Moreover, the application of modern irrigation techniques such as drip irrigation is one of the measures utilized for competent use of water [3]. Thus, the majority of the research has focused on inter-specific competition between oil seed crops using drip irrigation management under sandy soil conditions, especially Abdel Wahab et al. [4] reported that new reclaimed areas are mostly sandy soils and usually deficient in organic matter and poor in plant nutrients. However, the amount and timing of irrigation are two important aspects which determine the efficient use of applied water and maximizing crop yields [5]. No doubt that limited supply of water necessitates a shift in the production objectives from attainment of potential yield per unit of land to potential yield per unit of water [6].

However, increased intensity of cropping and introduction of high yielding varieties have resulted in considerable drain of potassium $(\mathrm{K})$ and crops are becoming responsive to $\mathrm{K}$ fertilization [7]. It has long been recognized that intercropping can give yield advantages over sole cropping. Intercrop productivity depends on the genetic constitution of component crops, growth environment (atmospheric and soil) and agronomic manipulation of micro-environment [8]. Intercropping sunflower (Helianthus annuus L.) in peanut (Arachis hypogaea L.) cultivated area can increase oil seed production per unit area and time [9]. Accordingly, $\mathrm{K}$ application not only increased sunflower yield [10] but also is the second most absorbed nutrient by the peanut crop [11]. K plays an important role in development, nutrition and production [12], especially Almeida et al. [13] expected that the peanut respond expressively to application of $\mathrm{K}$ fertilizer in soils with low $\mathrm{K}$ contents.

It is important to mention that appropriate plant density of sunflower could form suitable spatial arrangement of intercropping sunflower with peanut, especially Pal et al. [14] indicated that more seed yield was achieved when intra-plant spacing of $20 \mathrm{~cm}$ was maintained that significantly declined yield with further increase or decrease. A reduced sunflower planting density to $25 \%$ 
of the recommended plant density resulted in the highest peanut yield [15]. Little research has been done on the use of surface drip irrigation with increasing $\mathrm{K}$ fertilization to increase sunflower and peanut yields unit area ${ }^{-1}$, and low information is available to transfer this technology for Egyptian farmers under sandy soil conditions. Thus, the objective of this investigation was to evaluate competitive effects of intercropping sunflower and peanut under different drip irrigation water amounts and $\mathrm{K}$ fertilizer rates for increasing farmer profitability.

\section{Materials and Methods}

A two-year study was carried out at Ismailia Agricultural Research Station, Agricultural Research Centre, Ismailia governorate (Lat. $30^{\circ} 35^{\prime} 30^{\prime \prime} \mathrm{N}$, Long. $32^{\circ} 14^{\prime} 50 " \mathrm{E}, 10 \mathrm{~m}$ above the sea level), Egypt during 2016 and 2017 summer seasons. The objective of this investigation was to evaluate competitive effects of intercropping sunflower and peanut under different drip irrigation water amounts and $\mathrm{K}$ fertilizer rates for increasing farmer profitability. The treatments were the combinations of three irrigation water levels $(70 \%, 100 \%$ and $120 \%$ ETo), three $\mathrm{K}$ fertilizer rates $(\mathrm{K} 1=57, \mathrm{~K} 2=86$ and $\mathrm{K} 3=114 \mathrm{~K} 2 \mathrm{O} \mathrm{kg} / \mathrm{ha})$ and four sunflower and peanut intercropping patterns in a strip split plot design with three replications. The studied intercropping patterns are as follows:

- P1 = Peanut seeds were sown on both sides of all the raised beds $(1.2 \mathrm{~m}$ width) with $20 \mathrm{~cm}$ planting spacing (two plants together). Sunflower seeds were sown on one row above the one of the raised beds, with $20 \mathrm{~cm}$ planting spacing (one plant) and the following bed was left without intercropping sunflower seeds.

- P2 = Peanut seeds were sown on both sides of all the raised beds $(1.2 \mathrm{~m}$ width) with $20 \mathrm{~cm}$ planting spacing (two plants together). Sunflower seeds were sown on one row above the one of the raised beds, with $40 \mathrm{~cm}$ planting spacing (two plants together) on all the raised beds.

- P3 = Peanut seeds were sown on one row on the side of all the ridges $(0.6 \mathrm{~m}$ width) with $20 \mathrm{~cm}$ planting spacing (two plants together). Sunflower seeds were sown on the other side of the ridge, with $20 \mathrm{~cm}$ planting spacing (one plant) and the following three ridges were left without intercropping sunflower seeds.

- P4 = Peanut seeds were sown on one row on the side of all the ridges $(0.6 \mathrm{~m}$ width) with $20 \mathrm{~cm}$ planting spacing (two plants together). Sunflower seeds were sown on the other side of the ridge, with $40 \mathrm{~cm}$ planting spacing (one plant) and the following ridge was left without intercropping sunflower seeds.

- P5 = Sole peanut was sown with $100 \%$ of its recommended planting density on ridges ( $0.6 \mathrm{~m}$ width) with $20 \mathrm{~cm}$ planting spacing (two plants together).

- P6 = Sole sunflower was sown with $100 \%$ of its recommended planting density on ridges ( $0.6 \mathrm{~m}$ width) with $20 \mathrm{~cm}$ planting spacing (one plant). 
The yield and its components for each crop were only used to estimate comparative relationships and did not include in the statistical analysis. The studied sunflower and peanut intercropping patterns were planted with 166,600 and 20,825 plants per hectare, represented $100 \%$ and $25 \%$ of peanut and sunflower recommended planting densities.

Irrigation water treatments were randomly assigned to the horizontal plots, $\mathrm{K}$ fertilizer levels were allocated in vertical plots and intercropping patterns were distributed in sub plots. Plot area was $21.6 \mathrm{~m}^{2}$. Each sub plot consisted of 12 ridges, $3.0 \mathrm{~m}$ long and $0.6 \mathrm{~m}$ wide or 6 raised beds $3.0 \mathrm{~m}$ long and $1.2 \mathrm{~m}$ wide.

The soil of the experimental area is sandy texture with an average bulk density of $1.67 \mathrm{~g} / \mathrm{cm}^{3}$ and is alkaline in reaction with $\mathrm{pH}$ value of 8.20 . Average soil electrical conductivity in the saturated paste extract, over $0-60 \mathrm{~cm}$ depth, was about $0.33 \mathrm{dS} / \mathrm{m}$. The electrical conductivity of irrigation water was $0.50 \mathrm{dS} / \mathrm{m}$ and $\mathrm{pH}$ value was 7.55. Chemical and physical soil analyses were conducted by the standard methods described by Tan (1996). The analysis revealed that available NPK was $10.4,16.9$ and $64.4 \mathrm{ppm}$ in the experimental site.

Wheat was the preceding winter crop in both seasons. Calcium super phosphate $\left(15.5 \% \mathrm{P}_{2} \mathrm{O}_{5}\right)$ at rate of $476 \mathrm{~kg} / \mathrm{ha}$ was applied during soil preparation in the two summer seasons. Peanut cultivar Ismailial semi-erect and sunflower cultivar Sakha 53 were used and sown on May $26^{\text {th }}$ and May $30^{\text {th }}$ at 2016 and 2017 summer seasons, respectively. In the two seasons, peanut seeds were inoculated by Bradyrhizobium before seeding it.

Nitrogen fertilizer was added for sole peanut at a rate of $83.3 \mathrm{~kg} \mathrm{~N} / \mathrm{ha}$ as ammonium nitrate $(33.5 \% \mathrm{~N})$. Furthermore, nitrogen fertilizer was added for sole sunflower at a rate of $142.8 \mathrm{~kg} \mathrm{~N} / \mathrm{ha}$ as ammonium nitrate $(33.5 \% \mathrm{~N})$. With respect to sunflower intercropped with peanut, nitrogen fertilizer was added at a rate of $120.9 \mathrm{~kg} \mathrm{~N} / \mathrm{ha}$ as ammonium nitrate $(33.5 \% \mathrm{~N})$. Calcium sulfate at the rate of $1190 \mathrm{~kg} / \mathrm{ha}$ was applied for peanut after 35 days from peanut sowing. Recommended cultural practices for growing each crop were implemented as provided by the Egyptian Ministry of Agriculture.

\subsection{The Studied Traits}

\subsubsection{Peanut Studied Traits}

At harvest, the following traits were measured on ten bordered plants from each sub plot: numbers of pods and seeds per plant $(\mathrm{g})$ and seed yield per plant $(\mathrm{g})$. Pod yield of peanut per hectare (ton/ha) was recorded on the basis of experimental plot area by harvesting all plants of each sub plot.

\subsubsection{Sunflower Studied Traits}

At harvest, the following traits were measured on ten bordered plants from each sub plot: Number of leaves per plant, stem and head diameters $(\mathrm{cm})$ and head seed weight $(\mathrm{g})$. Seed yield per hectare $(\mathrm{kg} / \mathrm{ha})$ was recorded on the basis of experimental sub plot area by harvesting all plants of each plot. 


\subsubsection{Water Relation Measurements}

Irrigation water was applied every three days using the drip lateral lines connected to the sub-main line. Each lateral line is $20 \mathrm{~m}$ long and spaced at $0.7 \mathrm{~m}$ on the sub-main and is equipped with build-in emitters of $2 \mathrm{~L} / \mathrm{h}$ discharge rate spaced at $0.3 \mathrm{~m}$ on the lateral lines. A differential pressure tank was connected to the drip irrigation system to inject fertilizer via irrigation water. Evapotranspiration values (ETo) were calculated using BISm model [16]. The amounts of applied irrigation water were calculated according to the equation given by Vermeiren and Jopling [17] as follows:

$$
\mathrm{AIW}=\frac{\mathrm{ETo} \times \mathrm{I}}{\mathrm{Ea}(1-\mathrm{LR})}
$$

where: AIW $=$ depth of applied irrigation water $(\mathrm{mm})$, ETo $=$ reference evapotranspiration $(\mathrm{mm} /$ day). $\mathrm{I}=$ irrigation intervals (days), $\mathrm{Ea}=$ irrigation application efficiency of drip system $(\mathrm{Ea}=90 \%$ in the first seasons and $93 \%$ in the second season). $\mathrm{LR}=$ leaching requirements $(10 \%)$.

Crop water use was estimated by the method of soil moisture depletion according to Majumdar [18] as follows:

$$
\mathrm{WCU}=\sum_{\mathrm{i}=1}^{\mathrm{i}-4} \frac{\theta 2-\theta 1}{100} \times \mathrm{Bd} \times \mathrm{d}
$$

where: $\mathrm{WCU}=$ water consumptive use or actual evapotranspiration, ETa $(\mathrm{mm})$, $\mathrm{I}=$ number of soil layer, $\theta 2$ = soil moisture content after irrigation (\%, by mass), $\theta 1=$ soil moisture contents just before irrigation (\%, by mass), $\mathrm{Bd}=$ soil bulk density $\left(\mathrm{g} / \mathrm{cm}^{3}\right), \mathrm{d}=$ depth of soil layer $(\mathrm{mm})$.

Water equivalent ratio was calculated to quantify the amount of water that would be needed in single crops to achieve the same yield as produced with one unit of water in intercrop as stated by [19]:

$$
\mathrm{WER}=\mathrm{WER}_{\mathrm{A}}+\mathrm{WER}_{\mathrm{B}}=\left[\frac{\mathrm{Y}_{\text {int, } \mathrm{A}}}{\mathrm{WU}_{\mathrm{int}}} / \frac{\mathrm{Y}_{\text {mono }, \mathrm{A}}}{\mathrm{WU}_{\text {mono }, \mathrm{A}}}\right]+\left[\frac{\mathrm{Y}_{\text {int, } \mathrm{B}}}{\mathrm{WU}_{\text {int }}} / \frac{\mathrm{Y}_{\text {mono }, \mathrm{B}}}{\mathrm{WU}_{\text {mono }, \mathrm{B}}}\right] \quad \text { [4] }
$$

where: $\mathrm{WU}_{\mathrm{int}}, \mathrm{WU}_{\text {mono, } \mathrm{A}}$ and $\mathrm{WU}_{\text {mono, } \mathrm{B}}=$ water use efficiency of whole intercropping system, $A$ and $B$ in monocultures, respectively, $Y_{\text {int }}, Y_{\text {mono, } A}$ and $Y_{\text {int, } B}=$ yield of whole intercropping system, $\mathrm{A}$ and $\mathrm{B}$ in monocultures, respectively. If the WER $>1$, it suggests that the water utilization of intercropping is higher than that of monoculture. If WER $<1$, it shows that water utilization of intercropping is lower than that of monoculture.

\subsubsection{Competitive Relationships}

1) Land Equivalent Coefficient (LEC)

LEC is a measure of interaction concerned with the strength of relationship [20]. It is calculated as follows:

$$
\mathrm{LEC}=\mathrm{L}_{\mathrm{a}} \times \mathrm{L}_{\mathrm{b}}
$$

where: $L_{a}=$ relative yield of crop a (peanut) and $L_{b}=$ relative yield of crop $b$ (sunflower). 
2) System Productivity Index (SPI)

SPI was calculated as [21]:

$$
\mathrm{SPI}=\left[\left(\mathrm{S}_{\mathrm{A}} / \mathrm{L}_{\mathrm{B}}\right) \times \mathrm{L}_{\mathrm{b}}\right]+\mathrm{S}_{\mathrm{a}}
$$

where: $S_{A}$ and $L_{B}$ are the yield of peanut and sunflower in sole cropping, $S_{a}$ and $\mathrm{L}_{\mathrm{b}}$ are the yield of peanut and sunflower in intercropping.

3) Relative Crowding Coefficient (RCC)

RCC, which estimates the relative dominance of one species over the other in the intercropping system [22], was calculated as follows:

$$
\begin{gathered}
\mathrm{K}=\mathrm{K}_{\mathrm{a}} \times \mathrm{K}_{\mathrm{b}} \\
\mathrm{K}_{\mathrm{a}}=\mathrm{Y}_{\mathrm{ab}} \times \mathrm{Z}_{\mathrm{ba}} /\left[\left(\mathrm{Y}_{\mathrm{aa}}-\mathrm{Y}_{\mathrm{ab}}\right) \times \mathrm{Z}_{\mathrm{ab}}\right] ; \\
\mathrm{K}_{\mathrm{b}}=\mathrm{Y}_{\mathrm{ba}} \times \mathrm{Z}_{\mathrm{ab}} /\left[\left(\mathrm{Y}_{\mathrm{bb}}-\mathrm{Y}_{\mathrm{ba}}\right) \times \mathrm{Z}_{\mathrm{ba}}\right]
\end{gathered}
$$

where: $\mathrm{Y}_{\mathrm{aa}}=$ Pure stand yield of crop a (peanut); $\mathrm{Y}_{\mathrm{bb}}=$ Pure stand yield of crop $\mathrm{b}$ (sunflower); $\mathrm{Y}_{\mathrm{ab}}=$ Intercrop yield of crop a (peanut); $\mathrm{Y}_{\mathrm{ba}}=$ Intercrop yield of crop $b$ (sunflower); $Z_{a b}=$ The respective proportion of crop a in the intercropping system (peanut); $Z_{b a}=$ The respective proportion of crop $b$ in the intercropping system (sunflower).

4) Aggressivity (Agg)

Agg, which represents a simple measure of how much the relative yield increase in one crop is greater than the other in an intercropping system [23], was calculated as follows:

$$
\begin{aligned}
& A_{a b}=\left[Y_{a b} /\left(Y_{a a} \times Z_{a b}\right)\right]-\left[Y_{b a} /\left(Y_{b b} \times Z_{b a}\right)\right] ; \\
& A_{b a}=\left[Y_{b a} /\left(Y_{b b} \times Z_{b a}\right)\right]-\left[Y_{a b} /\left(Y_{a a} \times Z_{a b}\right)\right]
\end{aligned}
$$

5) Competitive Ratio (CR)

$\mathrm{CR}$ is an index which gives a more desirable competitive ability for the crops [24]. CR gives a better measurement of competitive ability of the crops and also is more advantageous. The $\mathrm{CR}$ is calculated according to the following formula:

$$
\begin{aligned}
& \mathrm{CR}_{\mathrm{a}}=\left(\operatorname{LER}_{\mathrm{a}} / \mathrm{LER}_{\mathrm{b}}\right)\left(\mathrm{Z}_{\mathrm{ba}} / \mathrm{Z}_{\mathrm{ab}}\right), \\
& \mathrm{CR}_{\mathrm{b}}=\left(\mathrm{LER}_{\mathrm{b}} / \mathrm{LER}_{\mathrm{a}}\right)\left(\mathrm{Z}_{\mathrm{ab}} / \mathrm{Z}_{\mathrm{ba}}\right)
\end{aligned}
$$

where: where $\operatorname{LER}_{\mathrm{a}}=\left(\mathrm{Y}_{\mathrm{ab}} / \mathrm{Y}_{\mathrm{aa}}\right), \mathrm{LER}_{\mathrm{b}}=\left(\mathrm{Y}_{\mathrm{ba}} / \mathrm{Y}_{\mathrm{bb}}\right)$. If $\mathrm{CR}_{\mathrm{a}}<1$, there is negative benefit and the crop can be grown in association. If $\mathrm{CR}_{\mathrm{a}}>1$, there is negative benefit. The reverse is true for $\mathrm{CR}_{\mathrm{b}}$.

6) Actual Yield Loss (AYL)

The partial actual yield losses, $\mathrm{AYL}_{\text {peanut }}$ or $\mathrm{AYL}_{\text {sunflower }}$ represent the relative decrease of yield per sowing proportion in intercropping of peanut and sunflower compared to corresponding yields in sole crops [25]. AYL is calculated according as follows:

$$
\begin{aligned}
& \mathrm{AYL}=\mathrm{AYL}_{\mathrm{a}}+\mathrm{AYL}_{\mathrm{b}}, \\
& \mathrm{AYL}_{\mathrm{a}}=\left[\left(\mathrm{Y}_{\mathrm{ab}} / \mathrm{Z}_{\mathrm{ab}}\right) /\left(\mathrm{Y}_{\mathrm{aa}} / \mathrm{Z}_{\mathrm{aa}}\right)\right]-1, \\
& \mathrm{AYL}_{\mathrm{b}}=\left[\left(\mathrm{Y}_{\mathrm{ba}} / \mathrm{Z}_{\mathrm{ba}}\right) /\left(\mathrm{Y}_{\mathrm{bb}} / \mathrm{Z}_{\mathrm{bb}}\right)\right]-1 .
\end{aligned}
$$


Positive AYL indicates an intercropping advantage; negative AYL indicates disadvantage in intercropping system.

\subsubsection{Intercropping Economic Advantage}

1) Monetary Advantage Index (MAI)

MAI suggests that the economic assessment should be in terms of the value of land saved; this could probably be most assessed on the basis of the rentable value of this land. MAI was calculated according to the formula, suggested by [23]. MAI $=[$ Value of combined intercrops $\times($ LER -1$)] /$ LER. MAI value indicates the profit of the cropping system.

2) Intercropping Advantage (IA)

IA contributing in the intercropping advantage of system [26], IA was calculated as:

$$
\begin{aligned}
& \mathrm{IA}_{\mathrm{a}}=\mathrm{AYL}_{\mathrm{a}} \times \mathrm{P}_{\mathrm{a}}, \\
& \mathrm{IA}_{\mathrm{b}}=\mathrm{AYL}_{\mathrm{b}} \times \mathrm{P}_{\mathrm{b}},
\end{aligned}
$$

where: $\mathrm{P}_{\mathrm{a}}=$ price of peanut (454 US\$ per ton) and $\mathrm{P}_{\mathrm{b}}=$ price of sunflower (188 US\$ per ton). The prices of peanut and sunflower were recorded from Bulletin of Statistical Cost Production and Net Return [27].

3) Income Equivalent Ratio (IER)

IER is similar in concept to LER, except that yield is measured in terms of net income, rather than plant product productivity. Because income is a function of both yield and crop price, even if the agronomic response is consistent, IER for intercrops may vary in different years as crop prices fluctuate. IER can be determined for systems involving more than two crops by summing the intercrop to sole crop yield (or net income) ratios of each crop included in the intercropping system. To calculate the IER obtained from intercropping a hectare of land were used. It was calculated by the formula developed by Ghaffarzadeh [28]:

$$
\operatorname{IER}=\left(\mathrm{I}_{\mathrm{ab}} / \mathrm{I}_{\mathrm{aa}}\right)+\left(\mathrm{I}_{\mathrm{ba}} / \mathrm{I}_{\mathrm{bb}}\right)
$$

where: $\mathrm{I}_{\mathrm{aa}}=$ Gross income in component a (peanut) in pure stand, $\mathrm{I}_{\mathrm{bb}}=$ Gross income in component $\mathrm{b}$ (sunflower) in pure stand, $\mathrm{I}_{\mathrm{ab}}=$ Gross income in component a (peanut) in mixed stand, $\mathrm{I}_{\mathrm{ba}}=$ Gross income in component $\mathrm{b}$ (sunflower) in mixed stand.

\subsection{Statistical Analysis}

Analysis of variance of the obtained results of each season was performed. The homogeneity test was conducted of error mean squares and accordingly, the combined analysis of the two experimental seasons was carried out. The measured variables were analyzed by ANOVA. Mean comparisons were performed using the least significant differences (L.S.D) test with a significance level of $5 \%$ [29]. The presented results are combined results of yield and its components of the two growing seasons. 


\section{Results and Discussion}

\subsection{Yield and Its Attributes}

\subsubsection{Irrigation Water Levels}

1) Peanut Traits

Data in Table 1 show that numbers of pods and seeds plant $^{-1}$, seed yield plant $^{-1}$ and pods yield ha $\mathrm{h}^{-1}$ were affected significantly by irrigation water applied levels in the combined data across the two seasons. Irrigation water $120 \%$ ETo

Table 1. Effect of irrigation water levels, $\mathrm{K}$ fertilizer and intercropping patterns on peanut traits averaged on the two seasons.

\begin{tabular}{|c|c|c|c|c|c|c|c|c|c|c|c|c|c|c|c|c|c|c|c|c|}
\hline \multirow{2}{*}{ Treat } & \multicolumn{5}{|c|}{ Pods plant ${ }^{-1}$ (no.) } & \multicolumn{5}{|c|}{ Seeds plant ${ }^{-1}$ (no.) } & \multicolumn{5}{|c|}{ Seed yield plant ${ }^{-1}(\mathrm{~g})$} & \multicolumn{5}{|c|}{ Pods yield ha $\mathrm{h}^{-1}(\mathrm{t})$} \\
\hline & P1 & P2 & P3 & P4 & Mean & P1 & P2 & P3 & P4 & Mean & P1 & P2 & P3 & P4 & Mean & P1 & P2 & P3 & P4 1 & Mean \\
\hline I1K1 & 14.53 & 14.58 & 14.42 & 14.41 & 14.49 & 35.86 & 35.81 & 35.79 & 35.84 & 35.83 & 26.81 & 26.84 & 26.80 & 26.85 & 26.82 & 2.52 & 2.41 & 2.43 & 2.38 & 2.43 \\
\hline $\mathrm{I} 1 \mathrm{~K} 2$ & 16.91 & 16.84 & 16.98 & 16.90 & 16.91 & 36.12 & 36.18 & 36.11 & 36.18 & 36.15 & 28.64 & 28.61 & 28.56 & 28.57 & 28.59 & 2.63 & 2.51 & 2.55 & 2.45 & 2.53 \\
\hline I1K3 & 18.01 & 18.62 & 17.98 & 17.95 & 18.14 & 36.64 & 36.45 & 36.60 & 36.52 & 36.55 & 30.39 & 30.15 & 30.19 & 30.40 & 30.28 & 2.70 & 2.61 & 2.64 & 2.53 & 2.62 \\
\hline Mean & 16.49 & 16.68 & 16.46 & 16.42 & 16.51 & 36.21 & 36.15 & 36.17 & 36.18 & 36.17 & 28.61 & 28.53 & 28.51 & 28.61 & 28.57 & 2.62 & 2.51 & 2.54 & 2.45 & 2.53 \\
\hline I2K1 & 18.73 & 18.68 & 18.75 & 18.64 & 18.70 & 39.63 & 39.63 & 39.69 & 39.64 & 39.64 & 29.27 & 29.26 & 29.22 & 29.21 & 29.24 & 3.19 & 3.09 & 3.08 & 3.07 & 3.10 \\
\hline I2K2 & 20.41 & 20.38 & 20.43 & 20.39 & 20.40 & 40.84 & 40.85 & 40.86 & 40.70 & 40.81 & 32.14 & 32.16 & 32.19 & 32.13 & 32.15 & 3.29 & 3.15 & 3.19 & 3.13 & 3.19 \\
\hline I2K3 & 21.85 & 21.77 & 21.45 & 21.35 & 21.61 & 41.16 & 41.30 & 41.37 & 41.38 & 41.30 & 33.82 & 33.71 & 33.53 & 33.62 & 33.67 & 3.35 & 3.22 & 3.28 & 3.16 & 3.25 \\
\hline Mean & 20.33 & 20.28 & 20.21 & 20.13 & 20.24 & 40.54 & 40.59 & 40.64 & 40.57 & 40.58 & 31.74 & 31.71 & 31.64 & 31.65 & 31.68 & 3.27 & 3.15 & 3.18 & 3.12 & 3.18 \\
\hline I3K1 & 18.23 & 18.20 & 18.16 & 18.24 & 18.20 & 39.87 & 39.63 & 39.73 & 39.61 & 39.71 & 30.25 & 30.32 & 30.20 & 30.21 & 30.24 & 3.22 & 3.09 & 3.09 & 3.04 & 3.11 \\
\hline I3K2 & 20.33 & 20.69 & 20.40 & 20.43 & 20.46 & 40.95 & 40.90 & 40.27 & 40.50 & 40.65 & 32.38 & 32.21 & 32.26 & 32.30 & 32.29 & 3.30 & 3.17 & 3.26 & 3.13 & 3.21 \\
\hline I3K3 & 21.37 & 21.32 & 21.68 & 21.41 & 21.45 & 41.43 & 41.41 & 41.31 & 41.81 & 41.49 & 33.44 & 33.27 & 33.19 & 33.23 & 33.28 & 3.34 & 3.22 & 3.29 & 3.19 & 3.26 \\
\hline Mean & 19.98 & 20.07 & 20.08 & 20.02 & 20.04 & 40.75 & 40.65 & 40.44 & 40.64 & 40.62 & 32.02 & 31.93 & 31.88 & 31.91 & 31.94 & 3.28 & 3.16 & 3.21 & 3.12 & 3.19 \\
\hline Ave K1 & 17.16 & 17.15 & 17.11 & 17.10 & 17.13 & 38.45 & 38.36 & 38.40 & 38.36 & 38.39 & 28.78 & 28.81 & 28.74 & 28.76 & 28.77 & 2.97 & 2.86 & 2.86 & 2.83 & 2.88 \\
\hline Ave K2 & 19.22 & 19.30 & 19.27 & 19.24 & 19.26 & 39.30 & 39.31 & 39.08 & 39.13 & 39.20 & 31.05 & 30.99 & 31.00 & 31.00 & 31.01 & 3.07 & 2.94 & 3.00 & 2.90 & 2.98 \\
\hline Ave K3 & 20.41 & 20.57 & 20.37 & 20.24 & 20.40 & 39.74 & 39.72 & 39.76 & 39.90 & 39.78 & 32.55 & 32.37 & 32.30 & 32.42 & 32.41 & 3.13 & 3.01 & 3.07 & 2.96 & 3.04 \\
\hline Ave $P$ & 18.93 & 19.01 & 18.92 & 18.86 & 18.93 & 39.16 & 39.13 & 39.08 & 39.13 & 39.13 & 30.79 & 30.72 & 30.68 & 30.72 & 30.73 & 3.06 & 2.94 & 2.98 & 2.89 & 2.97 \\
\hline & $S_{0.05} \mathrm{I}$ & Irrigati & on (I) & & 0.21 & & & & & 0.17 & & & & & 0.28 & & & & & 0.45 \\
\hline & $\mathrm{SD}_{0.05} \mathrm{~K}$ & fertili & zer $(K)$ & & 0.16 & & & & & 0.08 & & & & & 0.17 & & & & & 0.15 \\
\hline LSD & $\partial_{0.05}$ Inte & ercrop & ping ( & & N.S. & & & & & N.S. & & & & & N.S. & & & & & N.S. \\
\hline & $\mathrm{LSD}_{0}$ & $0.05 \mathrm{I} \times$ & & & 0.24 & & & & & 0.17 & & & & & 0.28 & & & & & N.S. \\
\hline & $\mathrm{LSD}_{0}$ & $0.05 . \mathrm{I} \times$ & & & N.S. & & & & & N.S. & & & & & N.S. & & & & & N.S. \\
\hline & $\mathrm{LSD}_{0}$ & $0.05 \mathrm{~K} \times$ & & & N.S. & & & & & N.S. & & & & & N.S. & & & & & N.S. \\
\hline & $\mathrm{LSD}_{0.05}$ & ${ }_{5} \mathrm{I} \times \mathrm{K}$ & $\times P$ & & N.S. & & & & & N.S. & & & & & N.S. & & & & & N.S. \\
\hline & Sole & peant & & & 23.03 & & & & & 41.77 & & & & & 35.66 & & & & & 3.43 \\
\hline
\end{tabular}


increased significantly numbers of pods and seeds plant ${ }^{-1}$, seed yield plant ${ }^{-1}$, pod yield $\mathrm{ha}^{-1}$ in comparison with those with applications of $70 \%$ and $100 \%$ ETo the combined data across the two seasons. With respect to irrigation water level $70 \%$ Eto, numbers of pods and seeds plant ${ }^{-1}$, seed yield plant ${ }^{-1}$ and pods yield ha ${ }^{-1}$ were decreased significantly by $17.61 \%, 10.95 \%, 10.55 \%$ and $20.68 \%$, respectively, in comparison with those with application of $120 \%$ ETo in the combined data across the two seasons (Table 1). These results may be due to the lowest irrigation water level closed stomata and thereby reduced activity of photosynthetic enzymes and photosynthesis process. Similar results were obtained by Rao et al. [30] who concluded that severe water stress from emergence to maturity resulted in lowering pod yields. It is important to mention that there were no significant differences between two irrigation water levels; $100 \%$ and $120 \%$ ETo for all the studied peanut traits.

Excessive water can cause excessive vegetative growth and a greater leaf area index, but restrict root growth and development [31].

2) Sunflower Traits

Data in Table 2 show that number of leaves plant ${ }^{-1}$, stem and head diameters, head seed weight and seed yield $\mathrm{ha}^{-1}$ were affected significantly by irrigation water applied levels in the combined data across the two seasons. Increasing irrigation water level from $70 \%$ to $120 \%$ caused significant increments in number of leaves plant ${ }^{-1}$, stem and head diameters, head seed weight and seed yield $\mathrm{ha}^{-1}$ in the combined data across the two seasons.

With respect to irrigation water level 70\% ETo, number of leaves plant ${ }^{-1}$, stem and head diameters, head seed weight and seed yield ha $^{-1}$ were decreased significantly by $4.00 \%, 7.25 \%, 22.83 \%, 8.79 \%$ and $34.86 \%$, respectively, in comparison with those of application $120 \%$ ETo in the combined data across the two seasons (Table 2). These results may be due to the lowest irrigation water level diminished plant water contents of sunflower, then leaf water potential, biomass, cell enlargement and growth with closing stomata due to mainly turgor loss [32] [33]. Consequently, the lowest irrigation water level resulted in lessening leaf growth and decreasing relative dry matter portioning into the root and shoot/root ratio [34] which reflected negatively on head seed weight. Sunflower plants that suffered from water deficit in the root zone have small root system and weak shoot growth and this in turn reduce both the vegetative growth and the yield [35].

There were no significant differences between two irrigation water levels; $100 \%$ and $120 \%$ Eto for number of leaves plant ${ }^{-1}$ and seed yield $\mathrm{ha}^{-1}$ in the combined data across the two seasons. These results are in same context with those observed by Szabo and Pepo [36] who found that irrigation effects do not come to expression and sunflower yields are often higher in rainfall areas. With respect to irrigation water level $120 \%$ ETo, stem and head diameters and head seed weight were increased significantly by $0.31 \%, 3.29 \%$ and $2.39 \%$, respectively, 
Table 2. Effect of irrigation water levels, K fertilizer and intercropping patterns on sunflower traits averaged on the two seasons.

\begin{tabular}{|c|c|c|c|c|c|c|c|c|c|c|c|c|c|c|c|}
\hline \multirow{2}{*}{ Treat } & \multicolumn{5}{|c|}{ Number of leaves/plant } & \multicolumn{5}{|c|}{ Stem diameter $(\mathrm{cm})$} & \multicolumn{5}{|c|}{ Head diameter $(\mathrm{cm})$} \\
\hline & P1 & P2 & P3 & P4 & Mean & P1 & P2 & P3 & P4 & Mean & P1 & P2 & P3 & P4 & Mean \\
\hline $\mathrm{I} 1 \mathrm{~K} 1$ & 20.54 & 20.47 & 20.25 & 20.14 & 20.35 & 2.92 & 2.91 & 2.92 & 2.89 & 2.91 & 18.63 & 18.33 & 18.59 & 18.28 & 18.46 \\
\hline $\mathrm{I} 1 \mathrm{~K} 2$ & 20.90 & 20.86 & 20.44 & 20.52 & 20.68 & 2.97 & 2.95 & 2.97 & 2.93 & 2.95 & 18.85 & 18.66 & 18.81 & 18.62 & 18.74 \\
\hline I1K3 & 20.90 & 20.82 & 20.72 & 20.76 & 20.80 & 2.99 & 2.97 & 2.98 & 2.95 & 2.97 & 18.85 & 18.51 & 18.80 & 18.49 & 18.66 \\
\hline Mean & 20.78 & 20.72 & 20.47 & 20.47 & 20.61 & 2.96 & 2.94 & 2.95 & 2.92 & 2.94 & 18.77 & 18.50 & 18.73 & 18.46 & 18.62 \\
\hline I2K1 & 21.28 & 21.20 & 21.08 & 21.11 & 21.17 & 3.14 & 3.13 & 3.12 & 3.09 & 3.12 & 23.30 & 22.95 & 23.25 & 22.90 & 23.10 \\
\hline I2K2 & 21.39 & 21.33 & 21.24 & 21.24 & 21.30 & 3.19 & 3.16 & 3.20 & 3.17 & 3.18 & 23.60 & 23.35 & 23.54 & 23.52 & 23.50 \\
\hline I2K3 & 21.50 & 21.40 & 21.35 & 21.39 & 21.41 & 3.20 & 3.20 & 3.20 & 3.17 & 3.19 & 23.66 & 23.38 & 23.60 & 23.34 & 23.49 \\
\hline Mean & 21.39 & 21.31 & 21.22 & 21.25 & 21.29 & 3.18 & 3.16 & 3.17 & 3.14 & 3.16 & 23.52 & 23.22 & 23.46 & 23.25 & 23.36 \\
\hline I3K1 & 21.44 & 21.37 & 21.34 & 21.34 & 21.37 & 3.14 & 3.12 & 3.14 & 3.11 & 3.13 & 23.44 & 24.06 & 23.39 & 24.03 & 23.73 \\
\hline I3K2 & 21.64 & 21.58 & 21.52 & 21.48 & 21.55 & 3.22 & 3.21 & 3.22 & 3.20 & 3.21 & 24.17 & 24.46 & 24.14 & 24.57 & 24.33 \\
\hline I3K3 & 21.55 & 21.48 & 21.41 & 21.46 & 21.48 & 3.21 & 3.17 & 3.19 & 3.15 & 3.18 & 24.21 & 24.64 & 24.10 & 24.37 & 24.33 \\
\hline Mean & 21.54 & 21.48 & 21.42 & 21.43 & 21.47 & 3.19 & 3.17 & 3.18 & 3.15 & 3.17 & 23.94 & 24.39 & 23.88 & 24.32 & 24.13 \\
\hline Ave K1 & 21.09 & 21.01 & 20.89 & 20.86 & 20.96 & 3.07 & 3.05 & 3.06 & 3.03 & 3.05 & 21.79 & 21.78 & 21.74 & 21.73 & 21.76 \\
\hline Ave K2 & 21.31 & 21.26 & 21.07 & 21.08 & 21.18 & 3.12 & 3.11 & 3.13 & 3.10 & 3.11 & 22.20 & 22.16 & 22.16 & 22.24 & 22.19 \\
\hline Ave K3 & 21.32 & 21.23 & 21.16 & 21.20 & 21.23 & 3.13 & 3.11 & 3.12 & 3.09 & 3.11 & 22.24 & 22.18 & 22.17 & 22.07 & 22.16 \\
\hline \multirow[t]{9}{*}{ Ave $P$} & 21.24 & 21.17 & 21.04 & 21.05 & 21.12 & 3.11 & 3.09 & 3.10 & 3.07 & 3.09 & 22.08 & 22.04 & 22.02 & 22.01 & 22.04 \\
\hline & \multicolumn{4}{|c|}{$\mathrm{LSD}_{0.05}$ Irrigation (I) } & 0.43 & & & & & 0.01 & & & & & 0.18 \\
\hline & \multicolumn{4}{|c|}{ LSD $_{0.05} \mathrm{~K}$ fertilizer $(\mathrm{K})$} & 0.08 & & & & & 0.01 & & & & & 0.18 \\
\hline & \multicolumn{4}{|c|}{$\mathrm{LSD}_{0.05}$ Intercropping (P) } & N.S. & & & & & 0.01 & & & & & N.S. \\
\hline & \multicolumn{4}{|c|}{$\mathrm{LSD}_{0.05} \mathrm{I} \times \mathrm{K}$} & 0.42 & & & & & 0.02 & & & & & N.S. \\
\hline & \multicolumn{3}{|c|}{$\mathrm{LSD}_{0.05} \mathrm{I} \times \mathrm{P}$} & & N.S. & & & & & N.S. & & & & & 0.23 \\
\hline & \multicolumn{3}{|c|}{$\mathrm{LSD}_{0.05} \mathrm{~K} \times \mathrm{P}$} & & 0.32 & & & & & N.S. & & & & & N.S. \\
\hline & \multicolumn{3}{|c|}{$\mathrm{LSD}_{0.05} \mathrm{I} \times \mathrm{K} \times \mathrm{P}$} & & N.S. & & & & & N.S. & & & & & N.S. \\
\hline & \multicolumn{3}{|c|}{ Sole sunflower } & & 21.09 & & & & & 2.97 & & & & & 21.86 \\
\hline \multirow{2}{*}{ Treat } & \multicolumn{7}{|c|}{ Head seed weight $(\mathrm{cm})$} & \multicolumn{8}{|c|}{ Seed yield $\mathrm{ha}^{-1}(\mathrm{~kg})$} \\
\hline & \multicolumn{2}{|c|}{ P1 } & P2 & P3 & \multicolumn{2}{|l|}{ P4 } & Mean & \multicolumn{2}{|l|}{ P1 } & P2 & \multicolumn{2}{|c|}{ P3 } & P4 & & Mean \\
\hline I1K1 & \multicolumn{2}{|c|}{57.86} & 57.16 & 57.80 & \multicolumn{2}{|l|}{57.10} & 57.48 & \multicolumn{2}{|c|}{740.33} & 649.33 & 700 & & 610.00 & & 675.00 \\
\hline $\mathrm{I} 1 \mathrm{~K} 2$ & & 9.15 & 58.78 & 59.10 & 58.70 & & 58.93 & 876.66 & & 753.33 & 824. & & 734.00 & & 797.00 \\
\hline I1K3 & & 0.67 & 59.25 & 60.58 & 59.38 & & 59.97 & 869.00 & & 768.66 & 859. & & 796.66 & & 823.33 \\
\hline Mean & & 9.23 & 58.39 & 59.16 & 58.39 & & 58.79 & 828.66 & & 723.77 & 794. & & 713.55 & & 765.11 \\
\hline $\mathrm{I} 2 \mathrm{~K} 1$ & & 1.22 & 60.87 & 61.20 & 60.82 & & 61.03 & 1113.33 & & 980.00 & 1045 & & 926.66 & & 1016.33 \\
\hline $\mathrm{I} 2 \mathrm{~K} 2$ & & 3.58 & 63.23 & 63.53 & 63.19 & & 63.38 & 1302.00 & & 1132.33 & 1279. & & 1111.66 & & 1206.33 \\
\hline $\mathrm{I} 2 \mathrm{~K} 3$ & & 4.25 & 64.59 & 64.31 & 64.69 & & 64.46 & 1301.00 & & 1129.00 & 1276 & & 1175.33 & & 1220.33 \\
\hline Mean & & 3.02 & 62.89 & 63.01 & 62.90 & & 62.95 & 1238.7 & & 1080.44 & 1200. & & 1071.22 & & 1147.66 \\
\hline
\end{tabular}




\begin{tabular}{|c|c|c|c|c|c|c|c|c|c|c|}
\hline \multicolumn{11}{|c|}{ Continued } \\
\hline I3K1 & 61.67 & 61.39 & 61.60 & 61.66 & 61.58 & 1121.66 & 997.66 & 1105.00 & 949.66 & 1043.50 \\
\hline $\mathrm{I} 3 \mathrm{~K} 2$ & 65.14 & 65.57 & 65.50 & 65.51 & 65.43 & 1319.33 & 1151.00 & 1309.66 & 1122.33 & 1225.58 \\
\hline I3K3 & 66.50 & 66.35 & 66.28 & 66.37 & 66.38 & 1334.66 & 1176.33 & 1305.66 & 1203.00 & 1254.91 \\
\hline Mean & 64.43 & 64.44 & 64.46 & 64.51 & 64.46 & 1258.55 & 1108.33 & 1240.11 & 1091.66 & 1174.66 \\
\hline Ave K1 & 60.25 & 59.80 & 60.20 & 59.86 & 60.03 & 991.77 & 875.66 & 950.22 & 828.77 & 911.61 \\
\hline Ave K2 & 62.62 & 62.52 & 62.71 & 62.46 & 62.58 & 1166.00 & 1012.22 & 1137.66 & 989.33 & 1076.30 \\
\hline Ave K3 & 63.81 & 63.40 & 63.72 & 63.48 & 63.60 & 1168.22 & 1024.66 & 1146.88 & 1058.33 & 1099.52 \\
\hline Ave $\mathbf{P}$ & 62.23 & 61.91 & 62.21 & 61.93 & 62.07 & 1108.66 & 970.85 & 1078.25 & 958.81 & 1029.14 \\
\hline \multicolumn{5}{|c|}{$\mathrm{LSD}_{0.05}$ Irrigation (I) } & 0.06 & & & & & 35.18 \\
\hline \multicolumn{5}{|c|}{$\mathrm{LSD}_{0.05} \mathrm{~K}$ fertilizer $(\mathrm{K})$} & 0.11 & & & & & 42.21 \\
\hline \multicolumn{5}{|c|}{$\mathrm{LSD}_{0.05}$ Intercropping (P) } & 0.14 & & & & & 30.49 \\
\hline \multicolumn{5}{|c|}{$\mathrm{LSD}_{0.05} \mathrm{I} \times \mathrm{K}$} & 0.16 & & & & & N.S. \\
\hline \multicolumn{5}{|c|}{$\mathrm{LSD}_{0.05} . \mathrm{I} \times \mathrm{P}$} & 0.20 & & & & & N.S. \\
\hline \multicolumn{5}{|c|}{$\mathrm{LSD}_{0.05} \mathrm{~K} \times \mathrm{P}$} & N.S. & & & & & N.S. \\
\hline \multicolumn{5}{|c|}{$\mathrm{LSD}_{0.05} \mathrm{I} \times \mathrm{K} \times \mathrm{P}$} & 0.44 & & & & & N.S. \\
\hline \multicolumn{5}{|c|}{ Sole sunflower } & 61.43 & & & & & 3442.66 \\
\hline
\end{tabular}

compared to those with application of $100 \%$ ETo in the combined data across the two seasons.

This can be attributed to the high growth parameters and the high metric potential and more availability of water in the root zone and these enhanced roots to absorb more water and increased the photosynthesis activity, which consequently increased the dry matter accumulation in plant organs. These results are in accordance with those obtained by Osman [37] who indicated that the yield parameters; stem and head diameters increased with increasing available soil moisture of sunflower crop under drip irrigation. Also, Abdel-Mawgoud et al. [35] noticed that increasing available soil moisture increased stem and head diameters and head weight.

\subsubsection{K Fertilizer}

\section{1) Peanut Traits}

Data in Table 1 show that numbers of pods and seeds plant ${ }^{-1}$, pods weight plant $^{-1}$, number of seeds plant ${ }^{-1}$, seed yield plant ${ }^{-1}$ and pod yield ha ${ }^{-1}$ were affected significantly by $\mathrm{K}$ fertilizer in the combined data across the two seasons. $\mathrm{K} 3$ fertilizer increased numbers of pods and seeds plant ${ }^{-1}$, seed yield plant ${ }^{-1}$ and pod yield $\mathrm{ha}^{-1}$ compared with those that received $\mathrm{K} 1$ or K2 fertilizer in the combined data across the two seasons. With respect to $\mathrm{K} 3$ fertilizer, numbers of pods and seeds plant ${ }^{-1}$, seed yield plant ${ }^{-1}$ and pod yield ha ${ }^{-1}$ were increased significantly by $5.91 \%, 1.47 \%, 4.51 \%$ and $2.01 \%$, respectively, compared to those with 
application of $\mathrm{K} 2$ fertilizer in the combined data across the two seasons (Table 1). These results may be due to $\mathrm{K} 3$ fertilizer improved $\mathrm{CO}_{2}$ fixation because of better conductivity of stomata which increased carbohydrate production [38]. These results are in similar with those of Gabr [39] who revealed that applying K as soil application increased seed yield.

2) Sunflower Traits

Data in Table 2 show that number of leaves plant $^{-1}$, stem and head diameters, head seed weight and seed yield $\mathrm{ha}^{-1}$ were affected significantly by $\mathrm{K}$ fertilizer in the combined data across the two seasons. K3 fertilizer caused significant increments in number of leaves plant ${ }^{-1}$, stem and head diameters, head seed weight and seed yield $\mathrm{ha}^{-1}$ in the combined data across the two seasons. With respect to $\mathrm{K} 3$ fertilizer, head seed weight was increased significantly by $1.62 \%$ compared to those with application of $\mathrm{K} 2$ fertilizer in the combined data across the two seasons (Table 2). These results may be due to $\mathrm{K} 3$ fertilizer improved $\mathrm{CO}_{2}$ fixation because of better conductivity of stomata which increased carbohydrate production [38].

\subsubsection{Intercropping Patterns}

1) Peanut Traits

Data in Table 1 show that numbers of pods and seeds plant $^{-1}$, seed yield plant $^{-1}$ and pod yield ha ${ }^{-1}$ were not affected significantly by $\mathrm{K}$ fertilizer in the combined data across the two seasons. These results could be due to all intercropping patterns of sunflower had similar effects on peanut during growth and development.

2) Sunflower Traits

Data in Table 2 show that stem diameter, head seed weight and seed yield ha ${ }^{-1}$ were affected significantly by intercropping patterns in the combined data across the two seasons, meanwhile number of leaves plant ${ }^{-1}$ and head diameter were not affected. P1 intercropping pattern had the highest values of stem diameter, head seed weight and seed yield $\mathrm{ha}^{-1}$ compared to the other intercropping patterns in the combined data across the two seasons. It seems that sunflower has a high capacity to achieve full light interception at narrow distance between sunflower hills. According to Andrade et al. [40], sunflower yield increase in response to narrow planting pattern is closely related to the improvement in light interception during the critical period for grain set. Proper arrangement of sunflower plants is important to get advantage of the free available solar radiation in crop production [41]. Similar results were obtained by Khan and Akmal [42] who showed that planting geometry of $90 \times 15.5 \mathrm{~cm}$ recorded higher yield than planting geometry $70 \times 20 \mathrm{~cm}$.

\subsubsection{The interaction between Irrigation Water Levels and $K$ Fertilizer \\ 1) Peanut Traits}

The interaction between irrigation water levels and $\mathrm{K}$ fertilizer affected sig- 
nificantly numbers of pods and seeds plant ${ }^{-1}$ and seed yield plant ${ }^{-1}$ in the combined data across the two seasons, meanwhile pod yield $\mathrm{ha}^{-1}$ was not affected (Table 1). Peanut plants that irrigated with $100 \%$ ETo and received K3 fertilizer recorded the highest values of number of pods and seed yield plant ${ }^{-1}$ compared with the others. However, the highest number of seeds plant ${ }^{-1}$ was obtained by irrigation water level $120 \%$ ETo $\times \mathrm{K} 3$ fertilizer in the combined data across the two seasons. It could be deduced that higher availability of water with K3 fertilizer enabled peanut plants to increase productivity under intercropping culture. These results are parallel with those obtained by Gireshsingh and Mahindra [43] who revealed that the highest yield was achieved under drip irrigation at a fertilization rate of $360 \mathrm{~kg} \mathrm{ha}^{-1}$.

2) Sunflower Traits

The interaction between irrigation water levels and $\mathrm{K}$ fertilizer affected significantly number of leaves plant ${ }^{-1}$, stem diameter and head seed weight in the combined data across the two seasons, meanwhile head diameter and seed yield $\mathrm{ha}^{-1}$ were not affected (Table 2). Sunflower plants that irrigated with $100 \%$ ETo and received $\mathrm{K} 3$ fertilizer recorded the highest stem diameter compared with the others. However, the highest values of number of leaves plant ${ }^{-1}$ and head seed weight were obtained by irrigation water level $120 \%$ ETo $\times$ K3 fertilizer in the combined data across the two seasons. These data reveal that each of these two factors act dependently on these traits except head diameter and seed yield $\mathrm{ha}^{-1}$. These results are parallel with those obtained by Taha and Abbass [44] who showed that irrigation each 8 days with $\mathrm{K}$ fertilization resulted in the highest values for the above vegetative and yield parameters.

\subsubsection{The Interaction between Irrigation Water Levels and Intercropping Patterns}

1) Peanut Traits

All the studied peanut traits were not affected significantly by the interaction between irrigation water levels and intercropping patterns in the combined data across the two seasons (Table 1). It seems that the increase in yield attributes of peanut was equally statistical under all the treatments of this interaction. This result may be attributed to shading of adjacent sunflower plants interacted positively with irrigation water levels to furnish better above and under-ground conditions for peanut growth by making the surrounding environment with peanut more moister. These data reveal that intercropping patterns responded similarly to irrigation water levels for all the studied peanut traits. These results are in agreement with those obtained by El-Mehy et al. [15] who reported that the interaction between irrigation treatments and intercropping patterns had no significant effect on pod yield ha $\mathrm{h}^{-1}$ in both seasons.

2) Sunflower Traits

The interaction between irrigation water levels and intercropping patterns affected significantly head diameter and head seed weight in the combined data 
across the two seasons, meanwhile number of leaves plant ${ }^{-1}$, stem diameter and seed yield ha ${ }^{-1}$ were not affected (Table 2). Generally, P1 intercropping pattern hat irrigated with $120 \%$ ETo recorded the highest values of head diameter and head seed weight compared with the others. These data reveal that each of these two factors act dependently on head diameter and head seed weight. These results are parallel with those obtained by El-Mehy et al. [15] who demonstrated that head diameter and head weight were influenced significantly by interaction between irrigation treatments and intercropping patterns in both seasons.

\subsubsection{The Interaction between $\mathrm{K}$ Fertilizer and Intercropping Patterns}

1) Peanut Traits

Data in Table 1 show that all the studied peanut traits were not affected significantly by the interaction between $\mathrm{K}$ fertilizer and intercropping patterns in the combined data across the two seasons. It seems that the increase in yield attributes of peanut was equally statistical under all the treatments of this interaction. This result may be attributed to shading of adjacent sunflower plants interacted positively with $\mathrm{K}$ fertilizer to furnish better above and under-ground conditions for peanut growth. These data reveal that intercropping patterns responded similarly to $\mathrm{K}$ fertilizer for all the studied peanut traits.

2) Sunflower Traits

The interaction between $\mathrm{K}$ fertilizer and intercropping patterns affected significantly number of leaves plant ${ }^{-1}$ in the combined data across the two seasons, meanwhile stem and head diameters, head seed weight and seed yield ha ${ }^{-1}$ were not affected (Table 2). P1 intercropping pattern that received K3 fertilizer recorded the highest number of leaves plant ${ }^{-1}$ compared with the others. These data reveal that each of these two factors act dependently on number of leaves plant $^{-1}$.

\subsubsection{The Interaction among Irrigation Water Levels, K Fertilizer and Intercropping Patterns \\ 1) Peanut Traits}

Data in Table 1 show that all the studied peanut traits were not affected significantly by the interaction between irrigation water levels, $\mathrm{K}$ fertilizer and intercropping patterns in the combined data across the two seasons. It seems that the increase in yield attributes of peanut was equally statistical under all the treatments of this interaction. This result may be attributed to shading of adjacent sunflower plants interacted positively with irrigation water levels and $\mathrm{K}$ fertilizer to furnish better above and under-ground conditions for peanut growth. These data reveal that intercropping patterns responded similarly to irrigation water levels and $\mathrm{K}$ fertilizer for all the studied peanut traits.

2) Sunflower Traits

The interaction between irrigation water levels, $\mathrm{K}$ fertilizer and intercropping 
patterns affected significantly head seed weight in the combined data across the two seasons, meanwhile number of leaves plant ${ }^{-1}$, stem and head diameters, head seed weight and seed yield ha $\mathrm{a}^{-1}$ were not affected (Table 2). P1 intercropping pattern that irrigated with $120 \%$ ETo and received K3 fertilizer recorded the highest head seed weight compared with the others.

\subsection{Water Relations of Peanut and Sunflower Patterns}

The results in Table 3 indicated that increasing the applied irrigation water from $70 \%$ ETo to $120 \%$ ETo resulted in an increase in water consumptive use of peanut and sunflower intercropping patterns. The table also showed that the values of water equivalent ratio (WER) for all intercropping pattern were higher than 1.

The lowest values of WER were obtained under the application of $70 \%$ ETo, K1 fertilizer level and P4 intercropping patterns. The highest value was obtained under the application of $120 \%$ ETo, K3 fertilizer level and P1 intercropping pattern. Thus, the productivity of the unit of water can be increased by a value between 52\% - 56\% under 120\% ETo, K3 fertilizer level and P1 intercropping pattern.

Our results indicated that the highest values of water equivalent ratio were obtained from using 120\% ETo, K3 fertilizer level under P1 intercropping pattern, followed by $100 \%$ ETo, K3 fertilizer under P1 intercropping pattern. Similar results were obtained by El-Mehy et al. (15) who indicated that the highest value of water equivalent ratio was obtained with $120 \%$ ETo and $25 \%$ of sunflower planting density intercropped with $100 \%$ of peanut planting density, where its spatial arrangements was similar to what was implemented in our experiment under P1 intercropping pattern.

\subsection{Competitive Relationships}

\subsubsection{LEC}

LEC is a measure of interaction concerned with the strength of relationship. LEC is used for a two-crop mixture the minimum expected productivity coefficient (PC) is 25 percent, that is, a yield advantage is obtained if LEC value was exceeded 0.25 . The effects of irrigation water quantities, $\mathrm{K}$ fertilizer and intercropping patterns on the LEC of sunflower with peanut were exceeded 0.25 under all treatments except treatments that irrigated with 70\% ETo and treatments that irrigated with $100 \%$ and $120 \%$ ETo for P2 and P4 intercropping patterns (Table 4). LEC ranged from 0.11 for $\mathrm{P} 4$ intercropping pattern that irrigated with $70 \%$ ETo and received K1 fertilizer to 0.36 for P1 intercropping pattern that irrigated with 100 or $120 \%$ ETo and received K3 fertilizer.

\subsubsection{SPI}

The values of SPI were presented in Table 4 . The value of SPI in P1 intercropping pattern that irrigated with $120 \%$ Eto and received K3 fertilizer was the 
Table 3. Applied irrigation water, water consumptive use and water equivalent ratio for peanut and sunflower intercropping patterns (P) under irrigation treatments (I) and $\mathrm{K}$ fertilizer $(\mathrm{K})$ averaged over the two growing seasons.

\begin{tabular}{|c|c|c|c|c|c|}
\hline \multirow{2}{*}{ Treat } & \multicolumn{5}{|c|}{ Applied water $\left(\mathrm{m}^{3} / \mathrm{ha}\right)$} \\
\hline & P1 & P2 & P3 & P4 & Mean \\
\hline I1K1 & 3170 & 3170 & 3170 & 3170 & 3170 \\
\hline I1K2 & 3170 & 3170 & 3170 & 3170 & 3170 \\
\hline I1K3 & 3170 & 3170 & 3170 & 3170 & 3170 \\
\hline Mean & 3170 & 3170 & 3170 & 3170 & 3170 \\
\hline $\mathrm{I} 2 \mathrm{~K} 1$ & 3900 & 3900 & 3900 & 3900 & 3900 \\
\hline $\mathrm{I} 2 \mathrm{~K} 2$ & 3900 & 3900 & 3900 & 3900 & 3900 \\
\hline $\mathrm{I} 2 \mathrm{~K} 3$ & 3900 & 3900 & 3900 & 3900 & 3900 \\
\hline Mean & 3900 & 3900 & 3900 & 3900 & 3900 \\
\hline I3K1 & 4590 & 4590 & 4590 & 4590 & 4590 \\
\hline I3K2 & 4590 & 4590 & 4590 & 4590 & 4590 \\
\hline I3K3 & 4590 & 4590 & 4590 & 4590 & 4590 \\
\hline Mean & 4590 & 4590 & 4590 & 4590 & 4590 \\
\hline Peanut & 4590 & 4590 & 4590 & 4590 & 4590 \\
\hline Sunflower & 4590 & 4590 & 4590 & 4590 & 4590 \\
\hline \multirow{2}{*}{ Treat } & \multicolumn{5}{|c|}{ Water consumptive use $\left(\mathrm{m}^{3} / \mathrm{ha}\right)$} \\
\hline & P1 & P2 & P3 & P4 & Mean \\
\hline I1K1 & 2821 & 2758 & 2790 & 2726 & 2774 \\
\hline I1K2 & 2878 & 2805 & 2825 & 2786 & 2824 \\
\hline I1K3 & 2886 & 2829 & 2853 & 2790 & 2839 \\
\hline Mean & 2862 & 2797 & 2823 & 2767 & 2812 \\
\hline $\mathrm{I} 2 \mathrm{~K} 1$ & 3471 & 3393 & 3432 & 3354 & 3413 \\
\hline $\mathrm{I} 2 \mathrm{~K} 2$ & 3510 & 3452 & 3476 & 3315 & 3438 \\
\hline $\mathrm{I} 2 \mathrm{~K} 3$ & 3549 & 3480 & 3510 & 3276 & 3454 \\
\hline Mean & 3510 & 3441 & 3473 & 3315 & 3435 \\
\hline I3K1 & 4085 & 3993 & 4039 & 3947 & 4016 \\
\hline I3K2 & 4131 & 4062 & 4091 & 3902 & 4046 \\
\hline I3K3 & 4177 & 4096 & 4131 & 3856 & 4065 \\
\hline Mean & 4131 & 4050 & 4087 & 3902 & 4042 \\
\hline Peanut & 3630 & 3630 & 3630 & 3630 & 3630 \\
\hline Sunflower & 3400 & 3400 & 3400 & 3400 & 3400 \\
\hline \multirow{2}{*}{ Treat } & \multicolumn{5}{|c|}{ Water equivalent ratio } \\
\hline & P1 & P2 & P3 & P4 & Mean \\
\hline I1K1 & 1.05 & 1.03 & 1.04 & 1.02 & 1.03 \\
\hline I1K2 & 1.07 & 1.05 & 1.05 & 1.04 & 1.05 \\
\hline I1K3 & 1.08 & 1.05 & 1.06 & 1.04 & 1.06 \\
\hline Mean & 1.07 & 1.04 & 1.05 & 1.03 & 1.05 \\
\hline I2K1 & 1.29 & 1.26 & 1.28 & 1.25 & 1.27 \\
\hline $\mathrm{I} 2 \mathrm{~K} 2$ & 1.31 & 1.29 & 1.29 & 1.23 & 1.28 \\
\hline I2K3 & 1.32 & 1.30 & 1.31 & 1.22 & 1.29 \\
\hline Mean & 1.31 & 1.28 & 1.29 & 1.23 & 1.28 \\
\hline I3K1 & 1.52 & 1.49 & 1.50 & 1.47 & 1.50 \\
\hline I3K2 & 1.54 & 1.51 & 1.52 & 1.45 & 1.51 \\
\hline I3K3 & 1.56 & 1.53 & 1.54 & 1.44 & 1.51 \\
\hline Mean & 1.54 & 1.51 & 1.52 & 1.45 & 1.51 \\
\hline Peanut & 1.00 & 1.00 & 1.00 & 1.00 & 1.00 \\
\hline Sunflower & 1.00 & 1.00 & 1.00 & 1.00 & 1.00 \\
\hline
\end{tabular}


Table 4. Relative yields of peanut and sunflower, LEC and SPI under irrigation water levels, K fertilizer and intercropping patterns averaged on the two seasons.

\begin{tabular}{|c|c|c|c|c|c|c|c|c|c|c|c|c|c|c|c|c|c|c|c|c|}
\hline \multirow{2}{*}{ Treat } & \multicolumn{5}{|c|}{$\mathrm{L}$ (peanut) } & \multicolumn{5}{|c|}{ L (sunflower) } & \multicolumn{5}{|c|}{ LEC } & \multicolumn{5}{|c|}{ SPI } \\
\hline & P1 & P2 & P3 & P4 & Mean & P1 & P2 & P3 & P4 & Mean & P1 & P2 & P3 & P4 & Mean & P1 & P2 & P3 & P4 & Mean \\
\hline $\mathrm{I} 1 \mathrm{~K} 1$ & 0.73 & 0.70 & 0.70 & 0.69 & 0.70 & 0.21 & 0.18 & 0.20 & 0.17 & 0.19 & 0.15 & 0.12 & 0.14 & 0.11 & 0.13 & 3.25 & 3.04 & 3.12 & 2.98 & 3.09 \\
\hline $\mathrm{I} 1 \mathrm{~K} 2$ & 0.76 & 0.73 & 0.74 & 0.71 & 0.73 & 0.25 & 0.21 & 0.23 & 0.21 & 0.22 & 0.19 & 0.15 & 0.17 & 0.14 & 0.16 & 3.49 & 3.25 & 3.36 & 3.17 & 3.31 \\
\hline I1K3 & 0.78 & 0.76 & 0.76 & 0.73 & 0.75 & 0.25 & 0.22 & 0.24 & 0.23 & 0.23 & 0.19 & 0.16 & 0.18 & 0.16 & 0.17 & 3.55 & 3.36 & 3.48 & 3.31 & 3.43 \\
\hline $\mathrm{I} 2 \mathrm{~K} 1$ & 0.93 & 0.90 & 0.89 & 0.89 & 0.90 & 0.32 & 0.28 & 0.30 & 0.26 & 0.29 & 0.29 & 0.25 & 0.26 & 0.23 & 0.26 & 4.29 & 4.06 & 4.11 & 3.98 & 4.10 \\
\hline $\mathrm{I} 2 \mathrm{~K} 2$ & 0.95 & 0.91 & 0.93 & 0.91 & 0.92 & 0.37 & 0.32 & 0.37 & 0.32 & 0.34 & 0.35 & 0.29 & 0.34 & 0.29 & 0.31 & 4.58 & 4.27 & 4.45 & 4.23 & 4.38 \\
\hline I2K3 & 0.97 & 0.93 & 0.95 & 0.92 & 0.94 & 0.38 & 0.32 & 0.37 & 0.34 & 0.35 & 0.36 & 0.29 & 0.35 & 0.31 & 0.32 & 4.64 & 4.33 & 4.54 & 4.32 & 4.46 \\
\hline Mean & 0.95 & 0.91 & 0.92 & 0.90 & 0.92 & 0.35 & 0.31 & 0.34 & 0.31 & 0.32 & 0.33 & 0.28 & 0.31 & 0.27 & 0.29 & 4.49 & 4.22 & 4.37 & 4.18 & 4.31 \\
\hline I3K2 & 0.96 & 0.92 & 0.95 & 0.91 & 0.93 & 0.38 & 0.33 & 0.38 & 0.32 & 0.34 & 0.36 & 0.30 & 0.36 & 0.29 & 0.31 & 4.60 & 4.31 & 4.55 & 4.24 & 4.42 \\
\hline I3K3 & 0.97 & 0.93 & 0.95 & 0.93 & 0.94 & 0.38 & 0.34 & 0.37 & 0.34 & 0.35 & 0.36 & 0.31 & 0.35 & 0.31 & 0.32 & 4.66 & 4.38 & 4.58 & 4.38 & 4.50 \\
\hline Mean & 0.95 & 0.92 & 0.93 & 0.90 & 0.92 & 0.36 & 0.32 & 0.36 & 0.31 & 0.32 & 0.34 & 0.29 & 0.33 & 0.27 & 0.29 & 4.52 & 4.25 & 4.44 & 4.20 & 4.35 \\
\hline Sole & 1.00 & 1.00 & 1.00 & 1.00 & 1.00 & 1.00 & 1.00 & 1.00 & 1.00 & 1.00 & 1.00 & 1.00 & 1.00 & 1.00 & 1.00 & 1.00 & 1.00 & 1.00 & 1.00 & 1.00 \\
\hline
\end{tabular}

highest than the other treatments. This result implies a relatively stable productivity.

\subsubsection{RCC}

Data presented in Table 5 indicate that RCC had higher than the unit advantage in all treatments except some intercropping patterns that irrigated with 70\% ETo in the combined data across the two seasons. The best results for $\mathrm{K}$ were achieved by P1 intercropping pattern that irrigated with $100 \%$ or $120 \%$ Eto and received K3 fertilizer. A yield advantage occurred because the component crops differed in their utilization of growth resources in such a way that when they are grown in association, they are able to complement each other and to work better overall use environmental resources than when they were grown separately. This finding indicates that the inter-specific competition was reduced with increasing $\mathrm{K}$ fertilizer between peanut and sunflower and the competitive ability of intercropped peanut was improved. The inter-specific competitiveness played an important role in determining the species yields in intercropping system [45].

\subsubsection{Agg}

Data in Table 6 Show that sunflower was the dominant intercrop component in all intercropping patterns in the combined data across the two seasons. The best results for Agg were achieved by P1 intercropping pattern that irrigated with $120 \%$ Eto and received K3 fertilizer. Peanut was the dominated component.

The present results indicate clearly that the competition of sunflower to peanut P1 that irrigated with $120 \%$ Eto and received K3 fertilizer is less than P4 intercropping pattern with irrigated with $70 \%$ Eto and received K1 fertilizer. It is 
Table 5. RCC under irrigation water levels, K fertilizer and intercropping patterns averaged on the two seasons.

\begin{tabular}{|c|c|c|c|c|c|c|c|c|c|c|c|c|c|c|c|}
\hline \multirow{2}{*}{ Treat } & \multicolumn{5}{|c|}{$\mathrm{K}_{\text {peanut }}$} & \multicolumn{5}{|c|}{$\mathrm{K}_{\text {sunflower }}$} & \multicolumn{5}{|c|}{$\mathrm{RCC}$} \\
\hline & P1 & P2 & P3 & P4 & Mean & P1 & P2 & P3 & P4 & Mean & P1 & P2 & P3 & P4 & Mean \\
\hline $\mathrm{I} 1 \mathrm{~K} 1$ & 0.69 & 0.59 & 0.60 & 0.56 & 0.61 & 1.09 & 0.92 & 1.02 & 0.86 & 0.97 & 0.75 & 0.54 & 0.62 & 0.48 & 0.59 \\
\hline $\mathrm{I} 1 \mathrm{~K} 2$ & 0.82 & 0.68 & 0.72 & 0.62 & 0.71 & 1.36 & 1.12 & 1.25 & 1.08 & 1.20 & 1.12 & 0.76 & 0.91 & 0.67 & 0.85 \\
\hline $\mathrm{I} 1 \mathrm{~K} 3$ & 0.92 & 0.79 & 0.83 & 0.70 & 0.81 & 1.35 & 1.14 & 1.32 & 1.20 & 1.25 & 1.24 & 0.91 & 1.11 & 0.84 & 1.01 \\
\hline Mean & 0.80 & 0.68 & 0.71 & 0.62 & 0.70 & 1.26 & 1.06 & 1.19 & 1.04 & 1.14 & 1.02 & 0.72 & 0.85 & 0.65 & 0.80 \\
\hline $\mathrm{I} 2 \mathrm{~K} 1$ & 3.32 & 2.27 & 2.20 & 2.13 & 2.48 & 1.91 & 1.59 & 1.74 & 1.47 & 1.68 & 6.35 & 3.61 & 3.83 & 3.14 & 4.14 \\
\hline $\mathrm{I} 2 \mathrm{~K} 2$ & 5.87 & 2.81 & 3.32 & 2.60 & 3.65 & 2.43 & 1.96 & 2.36 & 1.90 & 2.16 & 14.29 & 5.51 & 7.86 & 4.97 & 7.71 \\
\hline $\mathrm{I} 2 \mathrm{~K} 3$ & 10.46 & 3.83 & 5.46 & 2.92 & 5.67 & 2.42 & 1.95 & 2.35 & 2.07 & 2.20 & 25.43 & 7.48 & 12.87 & 6.06 & 11.99 \\
\hline Mean & 5.10 & 2.81 & 3.18 & 2.51 & 3.40 & 2.24 & 1.82 & 2.14 & 1.80 & 2.00 & 11.48 & 5.14 & 6.80 & 4.54 & 6.70 \\
\hline I3K1 & 3.83 & 2.27 & 2.27 & 1.94 & 2.58 & 1.93 & 1.63 & 1.89 & 1.52 & 1.74 & 7.41 & 3.70 & 4.29 & 2.96 & 4.44 \\
\hline $\mathrm{I} 3 \mathrm{~K} 2$ & 6.34 & 3.04 & 4.79 & 2.60 & 4.19 & 2.48 & 2.00 & 2.45 & 1.93 & 2.22 & 15.77 & 6.12 & 11.77 & 5.04 & 9.00 \\
\hline I3K3 & 9.27 & 3.83 & 5.87 & 3.32 & 5.57 & 2.53 & 2.07 & 2.44 & 2.14 & 2.30 & 23.49 & 7.95 & 14.35 & 7.13 & 12.42 \\
\hline Mean & 5.46 & 2.92 & 3.64 & 2.51 & 3.63 & 2.30 & 1.89 & 2.25 & 1.85 & 2.07 & 12.60 & 5.55 & 8.21 & 4.67 & 7.39 \\
\hline Peanut & 1.00 & 1.00 & 1.00 & 1.00 & 1.00 & 1.00 & 1.00 & 1.00 & 1.00 & 1.00 & 1.00 & 1.00 & 1.00 & 1.00 & 1.00 \\
\hline Sunflower & 1.00 & 1.00 & 1.00 & 1.00 & 1.00 & 1.00 & 1.00 & 1.00 & 1.00 & 1.00 & 1.00 & 1.00 & 1.00 & 1.00 & 1.00 \\
\hline
\end{tabular}

Table 6. Agg and CR under irrigation water levels, $\mathrm{K}$ fertilizer and intercropping patterns averaged on the two seasons.

\begin{tabular}{|c|c|c|c|c|c|c|c|c|c|c|c|c|c|c|c|c|c|c|c|c|}
\hline \multirow{2}{*}{ Treat } & \multicolumn{5}{|c|}{$\mathrm{Agg}_{\text {peanut }}$} & \multicolumn{5}{|c|}{ Agg sunflower $_{\text {s. }}$} & \multicolumn{5}{|c|}{$\mathrm{CR}_{\text {peanut }}$} & \multicolumn{5}{|c|}{$\mathrm{CR}_{\text {sunflower }}$} \\
\hline & P1 & P2 & P3 & P4 & Mean & P1 & $\mathrm{P} 2$ & P3 & P4 & Mean & P1 & $\mathrm{P} 2$ & P3 & P4 & Mean & P1 & P2 & P3 & P4 & Mean \\
\hline I1K1 & & & & & & & & & & & & & & & & & & & & .08 \\
\hline I1K2 & 0.25 & -0.14 & -0.21 & & & & & & & & & & & & & & & 1.24 & 1.18 & .20 \\
\hline I1K3 & & -0.13 & -0.22 & -0.18 & & & 0.13 & 0.22 & 0.18 & & & & 0.79 & 0.79 & & & 1.15 & 1.26 & 1.26 & 1.22 \\
\hline Mean & & -0.10 & -0.18 & -0.11 & & 0.19 & 0.10 & 0.18 & 0.11 & & 9 & 0.86 & 0.80 & 0.88 & & & 1.11 & 1.24 & 1.12 & 18 \\
\hline I2K1 & -0.36 & -0.23 & -0.31 & -0.18 & & & & & 0.18 & & & 0.80 & 0.74 & 0.85 & & & 1.24 & 1.34 & 1.16 & 1.28 \\
\hline $\mathrm{I} 2 \mathrm{~K} 2$ & -0.55 & -0.39 & -0.55 & -0.37 & -0.47 & & 0.39 & 0.55 & 0.37 & & 0.64 & 0.71 & 0.62 & 0.71 & & & 1.40 & 1.59 & 1.40 & 1.47 \\
\hline $\mathrm{I} 2 \mathrm{~K} 3$ & & -0.37 & -0.52 & -0.44 & -0.46 & 0.53 & 0.37 & 0.52 & 0.44 & & 0.63 & 0.72 & 0.64 & 0.67 & & & 1.37 & 1.55 & 1.47 & 1.48 \\
\hline Mean & -0.48 & -0.33 & -0.46 & -0.33 & -0.40 & 0.48 & 0.33 & 0.46 & 0.33 & & 0.67 & 0.73 & 0.67 & 0.72 & & 1.47 & 1.36 & 1.47 & 1.37 & 1.39 \\
\hline I3K1 & -0.36 & -0.25 & -0.38 & -0.21 & -0.30 & 0.36 & 0.25 & 0.38 & 0.21 & 0.30 & 0.72 & 0.80 & 0.70 & 0.81 & 0.77 & 1.37 & 1.24 & 1.42 & 1.22 & 1.28 \\
\hline I3K2 & -0.57 & -0.41 & -0.57 & -0.39 & -0.48 & 0.57 & 0.41 & 0.57 & 0.39 & 0.48 & 0.63 & 0.69 & 0.62 & 0.71 & 0.68 & 1.58 & 1.43 & 1.60 & 1.40 & 1.46 \\
\hline I3K3 & -0.57 & -0.42 & -0.55 & -0.46 & -0.50 & 0.57 & 0.42 & 0.55 & 0.46 & 0.50 & 0.63 & 0.68 & 0.64 & 0.68 & 0.67 & 1.56 & 1.46 & 1.55 & 1.46 & 1.48 \\
\hline Mean & -0.50 & -0.36 & -0.50 & -0.35 & -0.43 & 0.50 & 0.36 & 0.50 & 0.35 & 0.43 & 0.65 & 0.71 & 0.64 & 0.72 & 0.71 & 1.51 & 1.39 & 1.54 & 1.37 & 1.39 \\
\hline Sole & 1.00 & 1.00 & 1.00 & 1.00 & 1.00 & 1.00 & 1.00 & 1.00 & 1.00 & 1.00 & 1.00 & 1.00 & 1.00 & 1.00 & 1.00 & 1.00 & 1.00 & 1.00 & 1.00 & 1.00 \\
\hline
\end{tabular}

clear that sunflower plants had higher competitive ability than peanut plants. Similar results were obtained by El-Mehy et al. [15] who found that sunflower was the dominant intercrop component whereas peanut was the dominated in both seasons. 


\subsubsection{CR}

The values of CR were presented in Table 6. The intercropped sunflower had a greater $\mathrm{CR}_{\text {sunflower }}$ compared with intercropped peanut in all treatments except $\mathrm{P} 4$ intercropping pattern that irrigated with $70 \%$ ETo and received K1 fertilizer. This indicates that the values of $\mathrm{CR}_{\text {sunflower }}$ were greater than 1.0 in all treatments except P4 intercropping pattern that irrigated with 70\% ETo and received K1 fertilizer, however, the values of $\mathrm{CR}_{\text {peanut }}$ were less than 1.0. There were increases in $\mathrm{CR}_{\text {sunflower }}$ values with increasing irrigation water and $\mathrm{K}$ fertilizer levels and $\mathrm{CR}_{\text {peanut }}$ had the opposite trend. $\mathrm{CR}$ value of intercropped peanut was lower than sunflower, meanwhile CR value of intercropped peanut in $\mathrm{P} 4$ intercropping pattern that irrigated with 70\% ETo and received K1 fertilizer because of the wide spacing of sunflower, this result may be promoted photosynthetic process of peanut and efficient $\mathrm{N}$-use with effective rhizobial associations under sandy soil conditions. Consequently, root system of peanut cv. Ismailia 1 developed and absorbed more moisture and nutrients from sandy soil as elongated roots cover more surface area in the experimental soil and as such fixed substantial quantity of $\mathrm{N}$ through nodulation on roots [46].

\subsubsection{AYL}

The values of AYL were presented in Table 7. The value of AYL $L_{\text {peanut }}$ was negative for all treatments as a result of inter-specific competition between both species for basic growth resources. Oppositely, the value of $\mathrm{AYL}_{\text {sunflower }}$ was positive in all treatments except intercropping patterns that irrigated with $70 \%$ ETo without regarding to $\mathrm{K}$ fertilizer, which has shown a yield advantage of intercropped sunflower with increasing irrigation water level between peanut and sunflower. The maximum values of AYL were obtained by P1 intercropping

Table 7. AYL under irrigation water levels, $\mathrm{K}$ fertilizer and intercropping patterns averaged on the two seasons.

\begin{tabular}{|c|c|c|c|c|c|c|c|c|c|c|c|c|c|c|c|}
\hline \multirow{2}{*}{ Treat } & \multicolumn{5}{|c|}{$A Y L_{\text {peanut }}$} & \multicolumn{5}{|c|}{$A Y L_{\text {sunflower }}$} & \multicolumn{5}{|c|}{ Total AYL } \\
\hline & P1 & P2 & P3 & P4 & Mean & P1 & P2 & P3 & P4 & Mean & P1 & P2 & P3 & P4 & Mean \\
\hline I1K1 & -0.27 & -0.30 & -0.30 & -0.31 & -0.30 & -0.13 & -0.25 & -0.18 & -0.29 & -0.22 & -0.40 & -0.55 & -0.48 & -0.60 & -0.52 \\
\hline $\mathrm{I} 1 \mathrm{~K} 2$ & -0.24 & -0.27 & -0.26 & -0.29 & -0.27 & 0.01 & -0.12 & -0.04 & -0.15 & -0.08 & -0.22 & -0.39 & -0.30 & -0.44 & -0.35 \\
\hline I1K3 & -0.22 & -0.24 & -0.24 & -0.27 & -0.25 & 0 & -0.11 & -0.01 & -0.08 & -0.04 & -0.22 & -0.35 & -0.25 & -0.35 & -0.29 \\
\hline Mean & -0.24 & -0.27 & -0.26 & -0.29 & -0.27 & -0.04 & -0.16 & -0.08 & -0.17 & -0.11 & -0.28 & -0.43 & -0.34 & -0.46 & -0.38 \\
\hline $\mathrm{I} 2 \mathrm{~K} 1$ & -0.07 & -0.10 & -0.11 & -0.11 & -0.10 & 0.29 & 0.13 & 0.20 & 0.06 & 0.17 & 0.22 & 0.03 & 0.09 & -0.04 & 0.07 \\
\hline $\mathrm{I} 2 \mathrm{~K} 2$ & -0.05 & -0.09 & -0.07 & -0.09 & -0.08 & 0.51 & 0.31 & 0.47 & 0.29 & 0.39 & 0.46 & 0.22 & 0.40 & 0.20 & 0.31 \\
\hline I2K3 & -0.03 & -0.07 & -0.05 & -0.08 & -0.06 & 0.51 & 0.30 & 0.47 & 0.36 & 0.41 & 0.48 & 0.23 & 0.42 & 0.28 & 0.35 \\
\hline Mean & -0.05 & -0.09 & -0.08 & -0.10 & -0.08 & 0.43 & 0.25 & 0.39 & 0.24 & 0.32 & 0.38 & 0.16 & 0.31 & 0.14 & 0.24 \\
\hline I3K1 & -0.07 & -0.10 & -0.10 & -0.12 & -0.10 & 0.30 & 0.15 & 0.27 & 0.09 & 0.20 & 0.23 & 0.05 & 0.17 & -0.02 & 0.10 \\
\hline $\mathrm{I} 3 \mathrm{~K} 2$ & -0.04 & -0.08 & -0.05 & -0.09 & -0.07 & 0.52 & 0.33 & 0.51 & 0.30 & 0.41 & 0.48 & 0.25 & 0.46 & 0.21 & 0.34 \\
\hline I3K 3 & -0.03 & -0.07 & -0.05 & -0.07 & -0.06 & 0.54 & 0.36 & 0.51 & 0.39 & 0.45 & 0.51 & 0.29 & 0.46 & 0.32 & 0.39 \\
\hline Mean & -0.05 & -0.08 & -0.07 & -0.10 & -0.08 & 0.45 & 0.27 & 0.44 & 0.26 & 0.36 & 0.40 & 0.19 & 0.37 & 0.16 & 0.28 \\
\hline
\end{tabular}


pattern that irrigated with $120 \%$ Eto and received K3 fertilizer. The results suggest that competitive ability of peanut decreased and sunflower increased.

\subsection{Intercropping Economic Advantage}

\subsubsection{MAI}

The economic performance of the intercropping was evaluated to determine if sunflower and peanut combined yields are high enough for the farmers to adopt this system. The averages of MAI values of P1 intercropping pattern that irrigated with 120\% ETo and received K3 fertilizer were higher than the other treatments (Figure 1). There were gradual and consistent increases in MAI values with increasing $\mathrm{K}$ fertilizer of all intercropping patterns. P1 intercropping pattern that irrigated with $120 \%$ ETo and received K3 fertilizer resulted in high MAI and could be recommended.

\subsubsection{IA}

The values of IA were presented in Table 8. The values of $\mathrm{IA}_{\text {peanut }}$ were always negative, showing that peanut had a disadvantage in intercropping. The values of $\mathrm{IA}_{\text {sunflower }}$ in all treatments were positive except intercropping patterns that irrigated with $70 \%$ ETo had an opposite result. The values of IA were higher in P1 intercropping pattern that received $\mathrm{K} 3$ fertilizer and irrigated with $120 \%$ ETo than those of the other treatments. The results indicate that P1 intercropping pattern that received $\mathrm{K} 3$ fertilizer and irrigated with 120\% ETo had a highest economic advantage compared with the others.

\subsubsection{IER}

The values of IER were presented in Table 9. Within the treatments, the combined highest partial IER of peanut (0.97) and sunflower (0.38) were recorded by P1 intercropping pattern that irrigated with $120 \%$ Eto and received K3 fertilizer, meanwhile the lowest were recorded by $\mathrm{P} 4$ intercropping pattern that irrigated

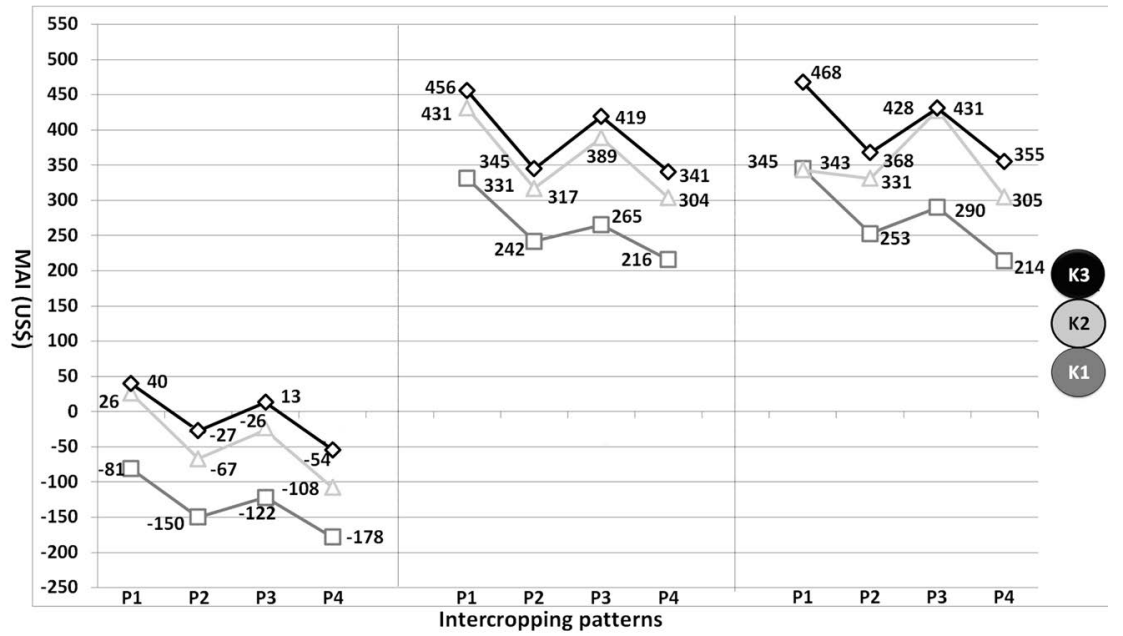

Figure 1. MAI (US\$) under irrigation water levels, K fertilizer and intercropping patterns averaged on the two seasons. 
Table 8. IA under irrigation water levels, $\mathrm{K}$ fertilizer and intercropping patterns averaged on the two seasons.

\begin{tabular}{|c|c|c|c|c|c|c|c|c|c|c|c|c|c|c|c|}
\hline \multirow{2}{*}{ Treat } & \multicolumn{5}{|c|}{$\mathrm{IA}_{\text {peanut }}$} & \multicolumn{5}{|c|}{ IA $_{\text {sunflower }}$} & \multicolumn{5}{|c|}{ Total IA } \\
\hline & P1 & P2 & P3 & P4 & Mean & P1 & P2 & P3 & P4 & Mean & P1 & P2 & P3 & P4 & Mean \\
\hline $\mathrm{I} 1 \mathrm{~K} 1$ & -122.58 & -136.20 & -136.20 & -140.74 & -136.20 & -26.23 & -48.09 & -34.97 & -54.65 & -41.53 & -148.81 & -184.29 & -171.17 & -195.39 & -177.73 \\
\hline $\mathrm{I} 1 \mathrm{~K} 2$ & -108.96 & -122.58 & -118.04 & -131.66 & -122.58 & 2.18 & -24.04 & -8.74 & -28.41 & -15.30 & -106.77 & -146.62 & -126.78 & -160.07 & -137.88 \\
\hline I1K3 & -99.88 & -108.96 & -108.96 & -122.58 & -113.50 & 0 & -21.86 & -2.18 & -15.30 & -8.74 & -99.88 & -130.82 & -111.14 & -137.88 & -122.24 \\
\hline Mean & -110.47 & -122.58 & -121.06 & -131.66 & -124.09 & -8.01 & -31.33 & -15.30 & -32.79 & -21.86 & -118.48 & -153.91 & -136.36 & -164.45 & -145.95 \\
\hline $\mathrm{I} 2 \mathrm{~K} 1$ & -31.78 & -45.40 & -49.94 & -49.94 & -45.40 & 54.65 & 26.23 & 39.34 & 13.11 & 32.79 & 22.87 & -19.16 & -10.59 & -36.82 & -12.60 \\
\hline $\mathrm{I} 2 \mathrm{~K} 2$ & -22.70 & -40.86 & -31.78 & -40.86 & -36.32 & 96.18 & 59.02 & 89.62 & 54.65 & 74.32 & 73.48 & 18.16 & 57.84 & 13.79 & 38.00 \\
\hline $\mathrm{I} 2 \mathrm{~K} 3$ & -13.62 & -31.78 & -22.70 & -36.32 & -27.24 & 96.18 & 56.83 & 89.62 & 67.76 & 78.69 & 82.56 & 25.05 & 66.92 & 31.44 & 51.45 \\
\hline I3K1 & -31.78 & -45.40 & -45.40 & -54.48 & -45.40 & 56.83 & 28.41 & 52.46 & 17.48 & 39.34 & 25.05 & -16.98 & 7.06 & -36.99 & -6.05 \\
\hline I3K2 & -18.16 & -36.32 & -22.70 & -40.86 & -31.78 & 98.37 & 63.39 & 96.18 & 56.83 & 78.69 & 80.21 & 27.07 & 73.48 & 15.97 & 46.91 \\
\hline I3K3 & -13.62 & -31.78 & -22.70 & -31.78 & -27.24 & 102.74 & 67.76 & 96.18 & 74.32 & 85.25 & 89.12 & 35.98 & 73.48 & 42.54 & 58.01 \\
\hline Mean & -21.18 & -37.83 & -30.26 & -42.37 & -34.80 & 85.98 & 53.19 & 81.61 & 49.55 & 67.76 & 64.79 & 15.36 & 51.34 & 7.17 & 32.96 \\
\hline
\end{tabular}

Table 9. IER under irrigation water levels, K fertilizer and intercropping patterns averaged on the two seasons.

\begin{tabular}{|c|c|c|c|c|c|c|c|c|c|c|c|c|c|c|c|}
\hline \multirow{2}{*}{ Treat } & \multicolumn{5}{|c|}{ IER $_{\text {peanut }}$} & \multicolumn{5}{|c|}{ IER $_{\text {sunflower }}$} & \multicolumn{5}{|c|}{ Total IER } \\
\hline & $\mathbf{P 1}$ & P2 & P3 & P4 & Mean & $\mathrm{P} 1$ & $\mathbf{P} 2$ & P3 & P4 & Mean & P1 & P2 & P3 & P4 & Mean \\
\hline $\mathrm{I} 1 \mathrm{~K} 2$ & 0.76 & 0.73 & 0.74 & 0.71 & 0.73 & 0.25 & 0.21 & 0.23 & 0.21 & 0.22 & 1.02 & 0.95 & 0.98 & 0.92 & 0.97 \\
\hline I1K3 & 0.78 & 0.76 & 0.76 & 0.73 & 0.75 & 0.25 & 0.22 & 0.24 & 0.23 & 0.23 & 1.03 & 0.98 & 1.01 & 0.96 & 1.00 \\
\hline Mean & 0.76 & 0.73 & 0.74 & 0.71 & 0.73 & 0.24 & 0.21 & 0.23 & 0.20 & 0.22 & 1.00 & 0.94 & 0.97 & 0.92 & 0.95 \\
\hline $\mathrm{I} 2 \mathrm{~K} 1$ & 0.93 & 0.90 & 0.89 & 0.89 & 0.90 & 0.32 & 0.28 & 0.30 & 0.26 & 0.29 & 1.25 & 1.18 & 1.20 & 1.16 & 1.19 \\
\hline $\mathrm{I} 2 \mathrm{~K} 2$ & 0.95 & 0.91 & 0.93 & 0.91 & 0.92 & 0.37 & 0.32 & 0.37 & 0.32 & 0.34 & 1.33 & 1.24 & 1.30 & 1.23 & 1.26 \\
\hline $\mathrm{I} 2 \mathrm{~K} 3$ & 0.97 & 0.93 & 0.95 & 0.92 & 0.94 & 0.38 & 0.32 & 0.37 & 0.34 & 0.35 & 1.35 & 1.26 & 1.32 & 1.26 & 1.29 \\
\hline $\mathrm{I} 3 \mathrm{~K} 1$ & 0.93 & 0.90 & 0.90 & 0.88 & 0.90 & 0.32 & 0.28 & 0.32 & 0.27 & 0.29 & 1.26 & 1.19 & 1.22 & 1.16 & 1.19 \\
\hline $\mathrm{I} 3 \mathrm{~K} 2$ & 0.96 & 0.92 & 0.95 & 0.91 & 0.93 & 0.38 & 0.33 & 0.38 & 0.32 & 0.34 & 1.34 & 1.25 & 1.33 & 1.23 & 1.27 \\
\hline I3K3 & 0.97 & 0.93 & 0.95 & 0.93 & 0.94 & 0.38 & 0.34 & 0.37 & 0.34 & 0.35 & 1.36 & 1.28 & 1.33 & 1.27 & 1.29 \\
\hline Mean & 0.95 & 0.92 & 0.93 & 0.90 & 0.92 & 0.36 & 0.32 & 0.36 & 0.31 & 0.32 & 1.32 & 1.24 & 1.29 & 1.22 & 1.25 \\
\hline Sole & 1.00 & 1.00 & 1.00 & 1.00 & 1.00 & 1.00 & 1.00 & 1.00 & 1.00 & 1.00 & 1.00 & 1.00 & 1.00 & 1.00 & 1.00 \\
\hline
\end{tabular}

with $70 \%$ Eto and received K1 fertilizer. IER shows an advantage from intercropping patterns over sole culture in terms of the use of environmental resources for plant growth with application of 120\% ETo that received K3 fertilizer. The combined yield advantage in terms of total IER indices was greatest in the cases of P1 intercropping pattern that irrigated with 120\% ETo and received K3 fertilizer, meanwhile P4 intercropping pattern that irrigated with $70 \%$ ETo 
and received $\mathrm{K} 1$ fertilizer gave a disadvantage of this intercropping pattern over sole culture.

\section{Conclusion}

Generally, competitive effects of intercropping peanut with sunflower appear to be a viable approach for reducing water dependency and improving profitability of Egyptian farmers under sandy soil conditions. P1 intercropping pattern decreased competitive pressure between the intercrops and increase WER with increase in K uptake by $30 \%$ over sole peanut under $120 \%$ drip water irrigation. Also, this cropping system increased MAI, IA and IER compared with sole peanut and it could be recommended.

\section{Conflicts of Interest}

The authors declare no conflicts of interest regarding the publication of this paper.

\section{References}

[1] Craine, J.M. and Dybzinski, R. (2013) Mechanisms of Plant Competition for Nutrients, Water and Light. Functional Ecology, 27, 833-840.

https://doi.org/10.1111/1365-2435.12081

[2] Sammis, T.W. (1980) Comparison of Sprinkler, Trickle, Subsurface, and Furrow Irrigation Methods for Row Crops. Agronomy Journal, 72, 701-704.

https://doi.org/10.2134/agronj1980.00021962007200050002x

[3] NWRP (2002) Facing the Challenge. National Conference: National Water Resources Plan Project, Planning Sector, Ministry of Water Resources \& Irrigation, Cairo, 29 April 2002, 5.

[4] Abdel Wahab, A.F., Biomy, A.H.M. and El Farghal, W.M. (2003) Effect of Some Natural Soil Amendments on Biological Nitrogen Fixation, Growth and Green Yield of Pea Plants Grown on Sandy Soils. Fayoum Journal of Agricultural Research and Environment, 17, 47-54.

[5] Sezen, S.M., Yazar, A., Kapur, B. and Tekin, S. (2011) Comparison of Drip and Sprinkler Irrigation Strategies on Sunflower Seed and Oil Yield and Quality under Mediterranean Climatic Conditions. Agricultural Water Management, 98, 1153-1161. https://doi.org/10.1016/j.agwat.2011.02.005

[6] Kadasiddappa, M.M., Rao, V.P., Reddy, K.Y., Ramulu, V., Devi, M.U. and Reddy, S.N. (2017) Effect of Irrigation (Drip/Surface) on Sunflower Growth, Seed and Oil Yield, Nutrient Uptake and Water Use Efficiency-A Review. Agricultural Reviews, 38, 152-15. https://doi.org/10.18805/ag.v38i02.7947

[7] Malik, S.M., Chaudhry, R.A. and Hussain, G. (1989) Crop Response to Potassium Application in the Punjab. Proceedings of Workshop on Role of K Improving Fertilizer Use Efficiency, UDFC/PARC, Islamabad, Pakistan, 21-22 March 1987.

[8] Mkamilo, G.S. (1998) Analysis of Yield Advantage in Intercropping. Master's Thesis, Wageningen Agricultural University, Wageningen.

[9] El-Sawy, W.A., El-baz, M.G. and Toaima, S.E.A. (2006) Response of Two Peanut Varieties to Intercropping with Sunflower under Different Sunflower Sowing Dates. Arab Journal of Nuclear Sciences and Applications, 21, 193-210. 
[10] Asadi, S. (2010) Influence of Different K Fertilizer Sources on Sunflower Production. 19th World Congress of Soil Science, Science and Research Campus, Tehran, Iran, 1-6 August 2010, 16-18.

[11] Veeramani, P. and Subrahmaniyan, K. (2012) Physical and Economic Optimum of Response Model for NPK Application in Irrigated Groundnut (Arachis hypogaea L.). Madras Agricultural Journal, 99, 526-529.

[12] Raza, M.A.S., Saleem, M.F., Shah, G.M., Jamil, M. and Khan, I.H. (2013) Potassium Applied under Drought Improves Physiological and Nutrient Uptake Performances of Wheat (Triticum aestivun L.). Journal of Soil Science and Plant Nutrition, 13, 175-185.

[13] Almeida, H.J., Pancelli, M.A., Prado, R.M., Cavalcante, V.S. and Cruz, F.J.R. (2015) Effect of Potassium on Nutritional Status and Productivity of Peanuts in Succession with Sugarcane. Journal of Soil Science and Plant Nutrition, 15, 1-10.

[14] Pal, M.S., Kumar, A. and Singh, R.P. (1997) Response of Spring Grown Sunflower (Helianthus annuus L.) Cultivars to Different Planting Geometry in Foothills of Utar Pradesh. Indian Journal of Agronomy, 42, 502-505.

[15] El-Mehy Amira, A., Taha, A.M. and Abd-Allah, A.M.M. (2018) Maximizing Land and Water Productivity by Intercropping Sunflower with Peanut under Sprinkler Irrigation. Alexandria Science Exchange Journal, 39, 144-160. https://doi.org/10.21608/asejaiqjsae.2018.5820

[16] Snyder, R.L., Orang, M., Bali, K. and Eching, S. (2004) Basic Irrigation Scheduling BISm.

http://www.waterplan.water.ca.gov/landwateruse/wateruse/Ag/CUP/California/cCli mate_Data_010804.xls

[17] Vermeiren, L. and Jopling, G.A. (1984) Localized Irrigation. Paper No. 36, FAO, Irrigation and Drainage Rome, Italy.

[18] Majumdar, D.K. (2002) Irrigation Water Management: Principles and Practice. 2nd Edition, Prentice-Hall of India, New Delhi, 487 p.

[19] Mao, L.L., Zhang, L.Z., Li, W.W., Werf, W.V.D., Sun, J.H., Spiertz, H. and Li, L. (2012) Yield Advantage and Water Saving in Maize/Pea Intercrop. Field Crops Research, 138, 11-20. https://doi.org/10.1016/j.fcr.2012.09.019

[20] Adetiloye, P.O., Ezedinma, F.O.C. and Okigbo, B.N. (1983) A Land Equivalent Coefficient Concept for the Evaluation of Competitive and Productive Interactions on Simple Complex Mixtures. Ecological Modelling, 19, 27-39.

https://doi.org/10.1016/0304-3800(83)90068-6

[21] Odo, P.E. (1991) Evaluating Short and Tall Sorghum Varieties in Mixtures with Cowpea in Sudan Savanna of Nigeria: LER, Grain Yield and System Productivity Index. Experimental Agriculture, 27, 435-441. https://doi.org/10.1017/S0014479700019426

[22] Banik, P., Midya, A., Sarkar, B.K. and Ghose, S.S. (2006) Wheat and Chickpea Intercropping Systems in an Additive Series Experiment: Advantages and Weed Smothering. European Journal of Agronomy, 24, 325-332. https://doi.org/10.1016/j.eja.2005.10.010

[23] Willey, R.W. (1979) Intercropping Its Importance and Research Needs. Part I: Competition and Yield Advantages. Field Crops Abstract, 32, 1-10.

[24] Dhima, K.V., Lithourgidis, A.S., Vasilakoglou, I.B. and Dordas, C.A. (2007) Competition Indices of Common Vetch and Cereal Intercrops in Two Seeding Ratio. Field Crops Research, 100, 249-256. https://doi.org/10.1016/j.fcr.2006.07.008 
[25] Banik, P., Sasmal, T., Ghosal, P.K. and Bagchi, D.K. (2000) Evaluation of Mustard (Brassica compestris var. Toria) and Legume Intercropping under 1M:1S and 2:1 Row-Replacement Series Systems. Journal of Agronomy and Crop Science, 185, 9-14. https://doi.org/10.1046/j.1439-037X.2000.00388.x

[26] Ghosh, P.K. (2004) Growth, Yield, Competition and Economic of Groundnut/Cereal Fodder Intercropping Systems in the Semi-Arid Tropics of India. Field Crops Research, 88, 217-237. https://doi.org/10.1016/j.fcr.2004.01.015

[27] Bulletin of Statistical Cost Production and Net Return (2017) Summer and Nili Field Crops and Vegetables and Fruit, Agriculture Statistics and Economic Sector, Ministry of Egyptian Agriculture and Land Reclamation, Part (2). Egypt.

[28] Ghaffarzadeh, M. (1997) Economic and Biological Benefits of Intercropping Berseem Clover with Oat in Corn-Soybeanoat Rotations. Journal of Production Agriculture, 10, 314-319. https://doi.org/10.2134/jpa1997.0314

[29] Gomez, K.A. and Gomez, A.A. (1984) Statistical Procedures for Agricultural Research. 2nd Edition, John Willey and Sons, Toronto, ON, Canada.

[30] Rao, R.C.N., Singh, S., Sivakumar, M.V.K., Srivastava, K.L. and Williams, J.H. (1984) Effect of Water Deficit at Different Growth Phases of Peanut. I. Yield Responses. Agronomy Journal, 77, 782-786. https://doi.org/10.2134/agronj1985.00021962007700050026x

[31] Boote, K.J., Stansell, J.R., Schubert, A.M. and Stone, J.F. (1982) Irrigation, Water Use, and Water Relations. In: Pattee, H.E. and Young, C.T., Eds., Peanut Science and Technology, Yoakum, American Peanut Research and Education Society, Texas, 164-205.

[32] Mozaffari, K., Arshi, Y. and Zeinali-Khanghaa, H. (1996) Research on the Effects of Water Stress on Some Morphophysiological Traits and Yield Components of Sunflower (Helianthus annuus L.). Seed and Plant, 12, 24-33.

[33] El-Midaoui, M., Serieys, H., Griveau, Y., Benbella, M., Talouizte, A., Berville, A. and Kaan, F. (2003) Effects of Osmotic and Water Stresses on Root and Shoot Morphology and Seed Yield in Sunflower (Helianthus annuus L.) Genotypes Bred for Morocco or Issued from Introgression with H. Argophyllus T. \& G. and H. Debilis Nutt. Helia, 26, 1-15. https://doi.org/10.2298/HEL0338001M

[34] Rauf, S. and Sadaqat, H.A. (2007) Effects of Varied Water Regimes on Root Length, Dry Matter Partitioning and Endogenous Plant Growth Regulators in Sunflower (Helianthus annuus L.). Journal of Plant Interactions, 2, 41-51. https://doi.org/10.1080/17429140701422512

[35] Abdel-Mawgoud, A.S.A., Gameh, M.A., Abd-Elaziz, S.H. and El-Sayed, M.M. (2009) Sunflower Water Relations at Various Irrigation Regimes with Modern Irrigation Systems under Climatic Conditions of Assiut Governorate, Upper Egypt. 13th International Water Technology Conference (IWTC 2009), Hurghada, Egypt, 12-15 March 2009, 589-609.

[36] Szabo, A. and Pepo, P. (2005) Effect of Agrotechnical and Meteorological Factors on Yield Formation in Sunflower Production. Cereal Research Communications, 33, 49-52. https://doi.org/10.1556/CRC.33.2005.1.11

[37] Osman, E.B.A. (2001) Productivity of Some Sunflower Hybrids by Using Modern Sydtems of Irrigation and Fertilization under Newly Reclaimed Soil. Master's Thesis, Assiut University, Assiut, Egypt.

[38] Marschner, H. (1995) Mineral Nutrition of Higher Plants. 2nd Edition, Academic Press, London, 889. 
[39] Gabr, E.M.A. (1998) Effect of Preceding Winter Crops and Potassium Fertilizer Levels on Growth and Yield of Intercropped Peanut and Sesame in New Sandy Soils. Proceeding of 8 th Conference in Agronomy Sciences, Suez Canal University, Ismailia, Egypt, 28-29 November 1998, 553-560.

[40] Andrade, F.H., Calvino, P., Cirilo, A. and Barbieri, P. (2002) Yield Responses to Narrows Rows Depend on Increased Radiation Interception. Agronomy Journal, 94, 975-980. https://doi.org/10.2134/agronj2002.0975

[41] Barros, J.F.C., Carvalho, M.D. and Basch, G. (2004) Response of Sunflower (Helianthus annuus L.) to Sowing Date and Plant Density under Mediterranean Conditions. European Journal of Agronomy, 21, 347-356.

https://doi.org/10.1016/j.eja.2003.10.005

[42] Khan, M.A. and Akmal, M. (2016) Plant Arrangement Effect on the Sunflower Yield and Yield Traits in Spring Season Crop. Sarhad Journal of Agriculture, 32, 151-155. https://doi.org/10.17582/journal.sja/2016.32.3.151.155

[43] Gireshsingh, M. and Mahindra, C. (2016) A Study on the Effects of Different Irrigation Methods and Fertilizer Regimes on Groundnut (Arachis hypogea var. cabri). Scholars Journal of Agriculture and Veterinary Sciences, 3, 9-19.

[44] Taha, M.M. and Abbass, J.A. (2008) Effect of Potassium Fertilization and Irrigation Intervals on Growth and Yield of Sunflower Helianthus annuus L. Jordan Journal of Agricultural Sciences, 4, 207-216.

[45] Zhang, L., Van der Werf, W., Zhang, S., Li, B. and Spiertz, J. (2007) Growth, Yield and Quality of Wheat and Cotton in Relay Strip Intercropping Systems. Field Crops Research, 103, 178-188. https://doi.org/10.1016/j.fcr.2007.06.002

[46] Abdel-Galil, M.A., Abdel-Wahab, S. and Abdel-Wahab, T. (2015) Effect of Some Preceded Peanut Cultivars on Wheat Yield and Agro-Economic Feasibility under Two Cropping Systems in Sandy Soil. Sustainable Agriculture Research, 4, 47-56. https://doi.org/10.5539/sar.v4n2p47 